\title{
Modelling-friendly life cycle inventory of underground mining of bauxite: A case study from Jajce mines in Bosnia and Herzegovina
}

Rudarsko-geološko-naftni zbornik

(The Mining-Geology-Petroleum Engineering Bulletin) UDC: $502: 6 ; 622.3$

DOI: $10.17794 / \operatorname{rgn} .2021 .3 \cdot 5$

Preliminary communication

\author{
Anamarija Grbeš' ${ }^{*}$; Ivo Galić ; Branimir Farkaš; Ivan Budeš4 \\ ${ }^{1}$ University of Zagreb, Faculty of Mining, Geology and Petroleum Engineering Pierottijeva 6, HR-10000 Zagreb \\ ${ }^{2}$ University of Zagreb, Faculty of Mining, Geology and Petroleum Engineering Pierottijeva 6, HR-10000 Zagreb \\ ${ }^{3}$ University of Zagreb, Faculty of Mining, Geology and Petroleum Engineering Pierottijeva 6, HR-10000 Zagreb \\ ${ }^{4}$ Rudnici boksita Jajce o.d.d. Divičani bb, Jajce, 70101, Bosnia and Herzegovina (Bauxite mines Jajce, open joint stock company)
}

\begin{abstract}
The objective of this paper is the study of the life cycle inventory (LCI) for underground mining of small, clustered deposits of Dinaric Alps-type bauxites, mined in the mountains near Jajce, a town in Bosnia and Herzegovina, in the period 2010-2020. Modelling of the life cycle inventory was done based on the company's internal reports and project documentation for a variant of the sublevel caving method that involves drilling and blasting. Four mines, located on three exploitation fields, were found in different phases of mine life, different levels of tectonic disturbances and different types of energy: diesel, electricity, and compressed air. The main results of this study are the inventory of underground bauxite exploitation made based on long-term data, the life cycle of one bauxite deposit, and the emission factors from blasting. Underground mining in this case proved to be energy intensive: an average of 52-92 $\mathrm{MJ} / \mathrm{t}$ was required (as opposed to 37 $\mathrm{MJ} / \mathrm{t}$ for surface bauxite exploitation in Italy). At the same time, underground bauxite exploitation caused only 5.6-6.4\% of the transformation of natural land that is above the mines and deposits. The operations relying on diesel fuel caused local emissions in the air and underground. The operation relying on electricity for DC locomotive and generation of the compressed air were without local emission into the air, although energy efficiency was probably reduced using compressed air as mechanical energy. At the state level, the impact depends on the country's energy mix, which is still quite dependent on fossil fuels. Engineering estimates of blasting emissions indicated detonators and ammonium nitrate explosives as a potentially important source of environmental impact. The mining industry would significantly benefit from cleaner energy in electricity generation (the energy sector) in Bosnia and Herzegovina. The path of air emissions in the underground system, especially lead and nitrogen compounds, needs to be further explored.
\end{abstract}

Keywords:

life cycle inventory; LCI; bauxite; mining method; emission factors

\section{Introduction}

The environmental life cycle assessment (LCA) is an internationally standardized environmental management method used to quantify environmental impacts related to products and services during all their stages of life (i.e. within the life cycle) (ILCD Handbook, EUR 24708 EN). In addition, the LCA is fostered as a technique in the integrated environmental impact assessment of policies and initiatives aiming to cut emissions and achieve climate neutrality (URL1). The main advantage of the LCA is its ability to identify and avoid the transfer of environmental burdens between the life stages of a product as a consequence of environmental improvement in the particular part of product life; or increase sectorial pressures as a result of a policy targeting a specific sector.

Corresponding author: Anamarija Grbeš agrbes@rgn.hr
The LCA has a relative character, which means that all impacts are expressed relative to the functional unit of the study. Every LCA study requires: 1 - a definition of the goal and scope within the system defined by its function, functional unit, and system boundary; 2 - a life cycle inventory (LCI) - a quantified list of relevant inputs and outputs; 3 - the application of the life cycle impact assessment method, "translating" all the inputs and outputs to the environmental indicators and their impacts; and finally, the interpretation of the results in relation to the goal and scope. (ILCD Handbook, EUR 24708 EN).

The flexibility of the LCA in assessing any product system and function (relative to the perspective of the study) limits the use of the study only to the defined purpose. As a result, it is difficult to compare environmental performances of apparently similar systems, such as ore produced in different countries (Bongono et al., 2020). The limited number of published LCA mining studies 
and the methodological differences, beginning with the functional unit definition, found and reported by AwuahOffei and Adekpedjou (2011) for the period until 2010, have not significantly improved, as shown in the study of Bongono et al. (2020). Albeit that the LCA method was standardized, and many guides exist, the mining sector is still waiting for guidelines that would address the mining LCA and strengthen the adoption of the life cycle approach in the mining sector.

LCA studies in the mining sector focus on results and environmental impacts of studied systems and specific mining operations: fuel/energy use (load and haul), land transformation (in open pit mining), and acid drainage (of sulfidic ores). These impacts depend on the type of mine (surface or underground), type of ore/rock, and the size of the prospect and the technology used (Norgate and Haque, 2010; Awuah-Offei and Adekpedjou, 2011; Ciacci et al., 2014; Grbeš 2014, 2016). While such studies can provide valuable results on energy intensity or global warming potential (GWP), or other issues, the system description in papers is often not sufficiently detailed for researchers and project developers oriented on changes. The inventories often do not allow further use and modelling for sustainability goals and innovation purposes. The original mining data and inventory in such a level of disaggregation that can be related to the ore type and quality, ore body, its context (geology, hydrology, topography), mining method, technology, and the geo-economic context are difficult to obtain, and many authors complained about uncertainties related to reliability (Ayres, 1995; Azapagic, 2004; Eckelman, 2010; Northey et al. 2014; Bartzas and Komnitsas, 2015).

This paper, undertaken within the EIT RM REEBAUX project (URL2), provides modelling of a friendly life-cycle inventory for the underground mining of highquality aluminium ore - bauxite in Bosnia and Herzegovina (BA). The inventory was provided by the company Bauxite Mines Jajce, for the period 2010-2020. In that period, Bosnia and Herzegovina was producing up to $0.5 \%$ of bauxite in the world, half of that was produced in the company Bauxite Mines Jajce. (Grbeš et al. 2018). In comparison, the major EU producer of primary aluminium is France, with only a $1 \%$ share in global production. Only $13 \%$ of primary aluminium in the EU is from domestic production. Due to the significance of aluminium for European industry and its relevance for strategic security, in 2020 bauxite was added to the EU list of critical raw materials (CRM). (European Commission, 2020).

Western Balkan countries (Albania, Bosnia and Herzegovina, Kosovo, Montenegro, Serbia, North Macedonia) and neighbouring EU members: Austria, Croatia, Hungary, and Slovenia, have always been important European suppliers of both, energy and non-energy raw materials. Strategic cooperation in raw material supply should be followed by cooperation in environment protection, research, and innovation in achieving climate neutrality by 2050 . To enable a fully effective ecological transition for Europe, the EU planned to support its immediate neighbours by creating a green agenda for the Western Balkans (European Commission 2019). Modelling friendly mining data and the adoption of the lifecycle approach in the mining industry will help set innovation targets and achieve Green Deal goals in the raw material supply chain in these countries.

\section{Methods}

The goal of this research was to create a modellingfriendly inventory of the underground mining of Dinaric Alps-type bauxites, mined in the mountains near Jajce, a town in Bosnia and Herzegovina, during the period 2010-2020. This was done by combining the descriptive and quantitative research of the documentation. Geology of the Jajce area and a description of the mining method was prepared by studying the previous exploration of the area and the project design. The mining operations were described based on the actual practice and the company's internal reports. Primary inputs (foreground inventory) were collected from the company's internal reports, the foreman's diary, the accounting service, and from interviews with the staff at operations. Literature and experts were consulted for the calculation of the emissions from blasting.

Inventory results provided a quantified description of mining at each site separately and for the whole company. The inventory of the management and administration was given separately. The mine inputs were given as: 1 - total mass, and 2 - relative mass (inputs divided by a quantity of the bauxite produced in the same period). Both total and relative mass were given in the inventory result for the whole observed period. Annual values were used for time-series analyses. In the discussion, the inventory results were compared between the mines, and with strip mining of bauxite from literature. The conclusion provides the main observations which were found.

The life cycle inventory (LCI) study is a variant of life cycle assessment, consisting of the goal and scope definition, inventory analysis, and the interpretation that summarizes and discusses the inventory results in relation to the defined goal and scope. Life cycle assessment (LCA) is an environmental management technique developed with the purpose of understanding and addressing the possible environmental impacts associated with products throughout their life cycle - from raw material acquisition through production, use, end-of-life treatment, recycling, and final disposal According to the ISO standard on LCA, the LCA can assist in identifying opportunities for improving the environmental performance of products at various points in their life cycle; in informing decision-makers in the industry, government, or non-government organizations; in the selection of relevant indicators of environmental performance, including measurement techniques; and in marketing In other cases, different techniques can be more appropriate: risk 


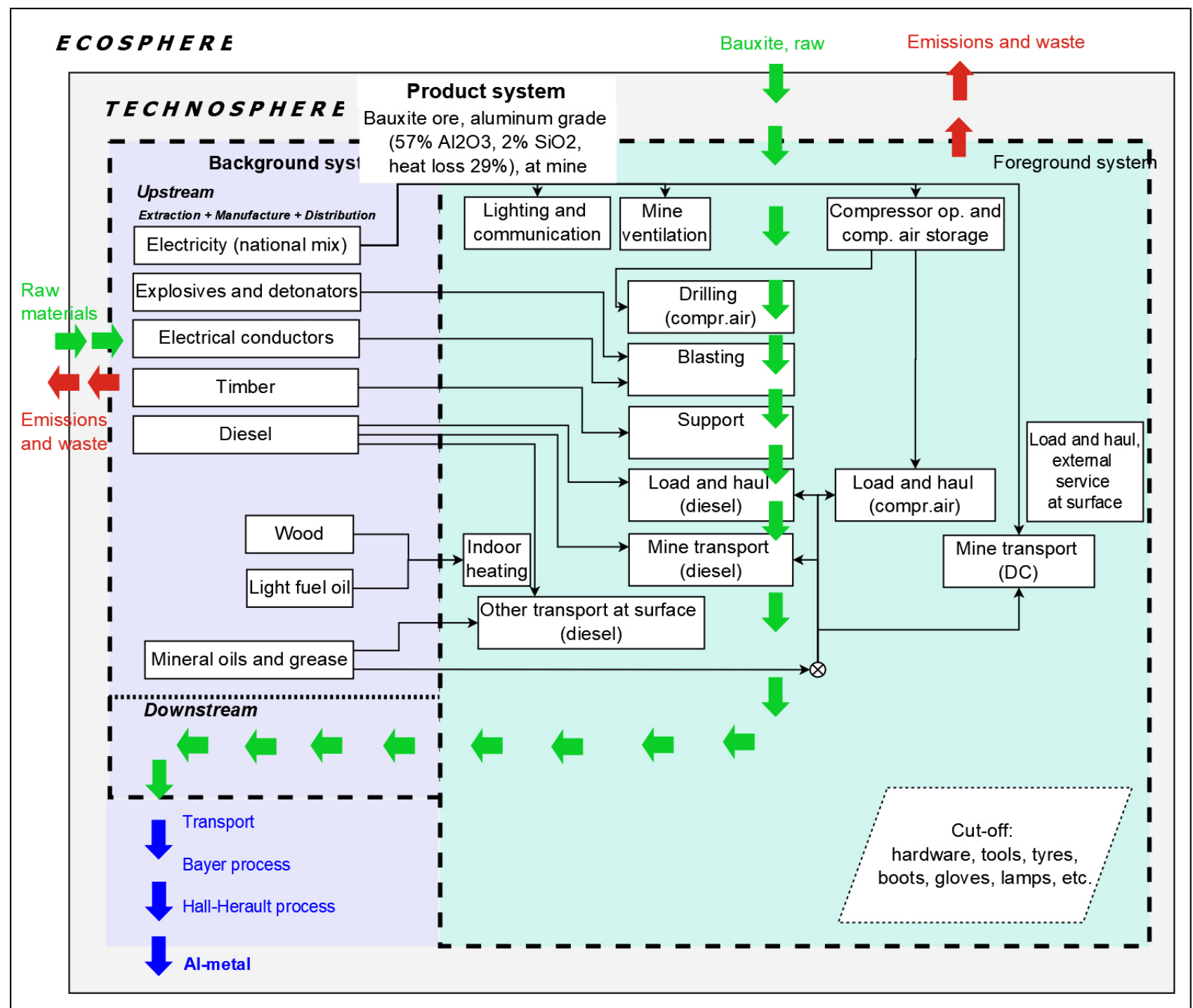

Figure 1: System boundary of bauxite production in the Bauxite Mines Jajce (adapted from Ereiz, 2019)

assessment, environmental performance evaluation, environmental auditing, or environmental impact assessment. (ISO 14040:2006 (E))

The reason for carrying out this study was to develop a life cycle inventory of underground mining of bauxite based on long-term data, to observe a complete inventory of mining a single deposit, from opening until closure, to understand how the inventory behaved within a longer period - how it differed depending on the fuel/technology choices, mine life stage, or rock mass quality (tectonics).

The function of the study was the production of bauxite in the Bauxite Mines Jajce in Bosnia and Herzegovina, in all its accounting units (mines), annually, in the period 2010-2020. A functional unit is $1 \mathrm{t}(1000 \mathrm{~kg})$ of mined bauxite. All inputs and outputs in the observed period were divided by the mass of bauxite produced in the corresponding period, in the respective mine(s). The LCI study focused on the foreground data (direct inputs). Upstream and downstream processes were ignored, considering that all mines share the upstream sup- ply of materials and energy, as well as the downstream transport to the processing plant (see Figure 1).

The main reference for the geology and tectonics of the Jajce area were the geological map (Marinkovic and Ahac, 1975) and the geological interpretation from the Main Design of the Bauxite Mines Jajce (Galić et al. 2005, 2006). The latter was based on the theses of geologists Dragičević and Tomić (Tomić 1983; Dragičević 1987). The source of the information on ore properties was the unpublished documentation on the exploration of bauxite ore bodies in the Bauxite Mines Jajce and reserves from Papeš et al. 2001.

Initial inputs and outputs were grouped into five categories, and collected separately for every accounting unit (mine):

1. Production, including mass of ore, length of access, and development;

2. Land use and transformation;

3. Labour, including number of employees and paid man-days; 
4. Mechanization by type of energy and operational purpose;

5. Energy - the electricity and diesel fuel;

6. Materials, as they were accounted in the company.

The calculation was performed for the following items: waste rock, energy, mining cables, composition of explosives, and detonators. The volume of the waste rock was calculated by multiplying the length of access and development with the profile of the corridors $\left(6 \mathrm{~m}^{2}\right)$. Energy was recalculated from $\mathrm{kWh}$ of electricity and volume of diesel fuel into Joules (MJ and/or GJ). The data on consumption of mining cables was unavailable. Due to this fact, assumptions and calculations on mining cable use were made based on the master thesis of Ereiz (2019). For mass balances in explosives and detonators, the Laboratory for Testing Explosives was consulted, as well as the previous work of Ereiz (2019), literature sources such as a technical encyclopaedia (Eržen and Sabioncello, 1969), and a textbook on chemistry for miners (Orlović-Leko, 2013).

\section{Results}

The study was performed for underground mining of the small deposits of bauxite in the mountains near Jajce, a town in Bosnia and Herzegovina. The company Rudnici boksita Jajce o.d.d (Bauxite Mines Jajce) has been mining the bauxites of Jajce for more than fifty years. Currently, the bauxite ore from the Bauxite Mines Jajce is mined at three exploitation fields: Crvene Stijene, Poljane, and Bešpelj-Pećine (see Figure 2). The deposit L-34, placed in the Bešpelj area, was mined in the period 2010-2018, however, due to its distant location from main mine system of Bešpelj, it was accessed and mined separately. Due to that, it was accounted separately, enabling insight into the mining life of one deposit.

\subsection{Geology of the Jajce area}

Bauxite ore bodies in Bešpelj, same as other numerous sedimentary bauxite ore bodies at Jajce, originated during the emersion phase of the long-lasting Cretaceous marine carbonate sedimentation, now known as the area of the Internal Dinaric Alps. These bauxites occur within the shallow-marine succession of carbonate rocks (limestones and carbonate breccia), present in the footwall and the hanging-wall of the ore bodies. In the footwall, karstified Cretaceous Albian-Cenomanian limestones are predominant, while carbonate marlstone and calcarenites alternate in the hanging-wall (see Figure 2).

The underground system of Bešpelj is tectonically complex. Numerous observations of the sloping, overturned layers, numerous folds, and faults indicate intensive tectonic activity in the area shown on the geological map in Figure 2. The fundamental structural feature of the area are folds and faults. There are two structurally different areas, eastern and western. The eastern region,
Table 1. The average mineral and chemical composition of the Jajce bauxites (Papeš et al. 20o1)

\begin{tabular}{|l|l|l|l|}
\hline Mineral & \% & Oxide & \% \\
\hline Boehmite & 66.50 & $\mathrm{Al}_{2} \mathrm{O}_{3}$ & 57.66 \\
\hline Kaolinite & 3.90 & $\mathrm{SiO}_{2}$ & 2.00 \\
\hline Hematite & 29.90 & $\mathrm{Fe}_{2} \mathrm{O}_{3}$ & 24.77 \\
\hline Anatase & 0.70 & $\mathrm{TiO}_{2}$ & 2.60 \\
\hline Calcite & 1.50 & $\mathrm{CaO}$ & 0.05 \\
\hline Other & 1.40 & Heat loss & 28.83 \\
\hline
\end{tabular}

Table 2. The rock quality in the Jajce Mines

(Papeš et al. 20o1)

\begin{tabular}{|l|l|l|l|l|}
\hline Rock & $\begin{array}{l}\text { Compressive } \\
\text { strength, } \\
\boldsymbol{\sigma}(\mathbf{M P a})\end{array}$ & $\begin{array}{l}\text { Cohesion, } \\
\mathbf{c}(\mathbf{M P a})\end{array}$ & $\begin{array}{l}\text { Internal } \\
\text { friction, } \\
\boldsymbol{\varphi}\left(^{\circ}\right)\end{array}$ & $\begin{array}{l}\text { Volumetric } \\
\text { mass, } \\
\boldsymbol{\rho}\left(\mathbf{k g} / \mathbf{m}^{3}\right)\end{array}$ \\
\hline $\begin{array}{l}\text { Bauxite } \\
\text { ore }\end{array}$ & 1.80 & 0.450 & 45.0 & 2700 \\
\hline $\begin{array}{l}\text { Hanging } \\
\text { wall }\end{array}$ & 6.30 & 0.720 & 42.3 & 2700 \\
\hline Footwall & 4.32 & 0.720 & 40.5 & 2700 \\
\hline
\end{tabular}

which includes the bauxite district of the Poljane Mine and the Crvene Stijene Mine, is characterized by the Dinaric Alps structural type, oriented NW-SE. It is characterized by gentle folds and vertical to normal subvertical faults. In the area of Poljane, the axis of the syncline sinks with slightly laid wings $\left(10-30^{\circ}\right)$. In the north-eastern part of this area, the clustering of flysch is folding and overturning more intensely. The western area, with the bauxite district of Bešpelj, is more tectonically disturbed. Main structures (folds and faults) are oriented W-E. There are intricate tectonic relationships present, which is best seen in the concave structure of the Bešpelj (syncline). There are also significant displacements along normal faults. The most significant geological feature is the structural division on the east and west regions, separated by majorly horizontal faulting zone in the Crvene Stijene area. (Marinkovic and Ahac, 1975; Tomić 1983; Dragičević 1987; Galić et al. 2005, 2006).

Main ore mineral constituents are boehmite and hematite. The silica modulus $\left(\mathrm{Al}_{2} \mathrm{O}_{3} / \mathrm{SiO}_{2}\right)$ of the ore is 28 (see Table 1). The hanging wall and footwall have considerable mechanical strength (see Table 2) and the underground space in such rocks, depending on the tectonic disturbance, requires only occasional mine support (timber) or none at all (Papeš et al. 2001.).

\subsection{Mining method}

The sublevel caving method is an underground mining method in which the ore body is accessed by decline tunnels from the mountain side, developed from bottomup and from the top to the bottom of the deposit (levels), mined top-down and back-to-front consecutively, and hauled from the lowest level to the surface. The method 


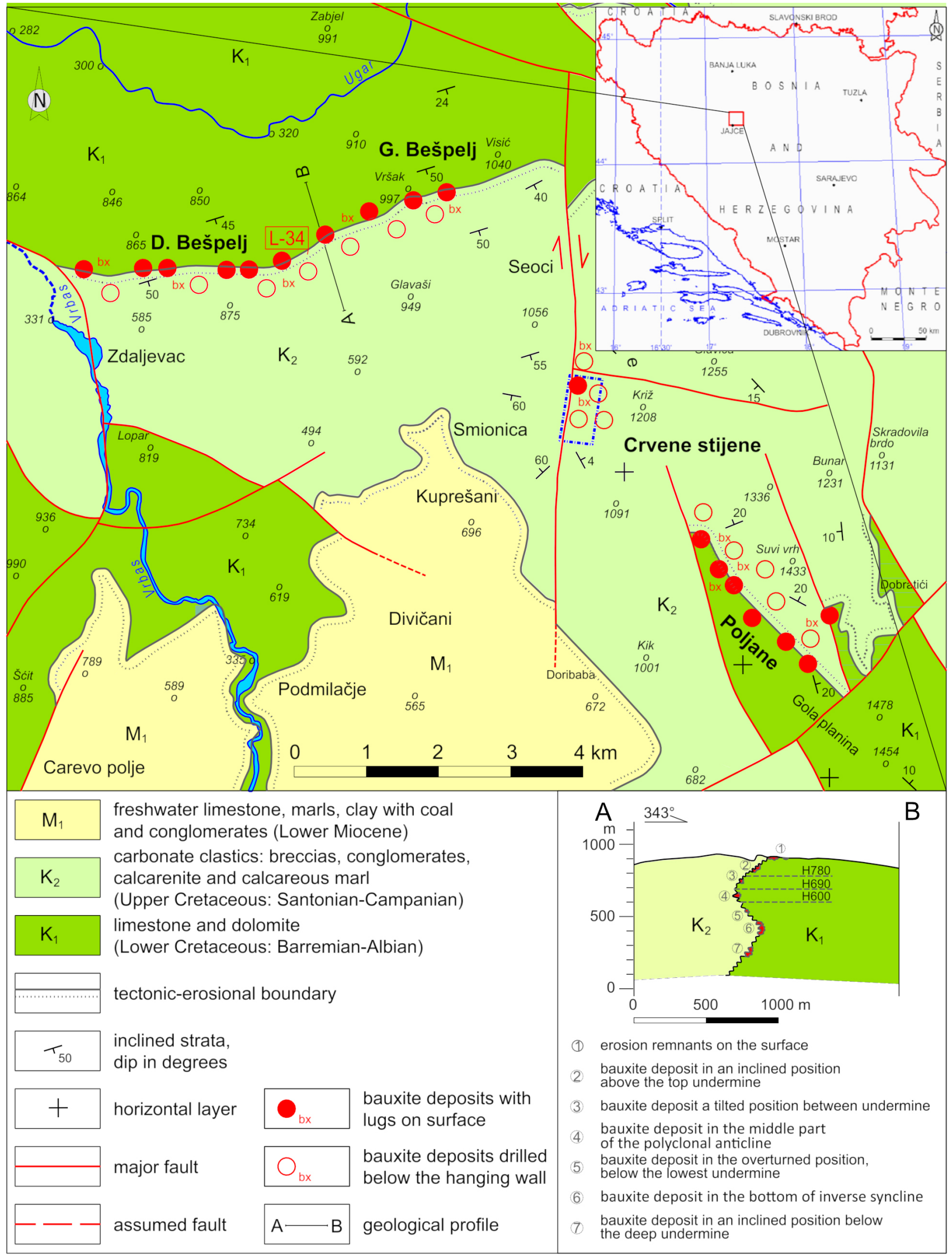

Figure 2: Geographical position and geological map of bauxite deposits at Jajce (Marinković \& Ahac, 1975; supplemented and adapted with exploration findings of Dragičević, 1981, 1987, 1997) 
is safe and flexible, with good work organization, high mechanization, concentration of work, and rationalized separate mining activities. These are all the preconditions for effective and relatively inexpensive mining. The ore is extracted by drilling and blasting. Blasting is designed to obtain suitable granulation for gravity transportation. This method requires a larger amount of preparation before the production can begin (Kvapil, 1992).

A typical variant of the sublevel caving method applied in the Bauxite Mines Jajce is shown in Table 3 and Figure 3. The deposit was accessed from the surface with two main corridors in decline: above the deposit, along the contact with the ore body (in the hanging wall) is the main directional corridor, and the main transport corridor is below the deposit (in the footwall). From the

Table 3. Specification of the sublevel caving mining method in the Jajce Mines (Galić et al., 2005)

\begin{tabular}{|l|l|}
\hline Mining method & Sublevel caving \\
\hline Ore extraction & Drilling and blasting \\
\hline Load and haul & Air loaders, diesel loaders \\
\hline Mine transport & $\begin{array}{l}\text { Gravity transport, DC (battery) } \\
\text { locomotive (train), diesel trucks }\end{array}$ \\
\hline
\end{tabular}

main transport corridor, the ventilation shaft and the shaft for the gravity transport were raised up to the main directional corridor. The production drift was directed from the shaft, one level below the top of the deposit, entering the deposit sideways, until the back-wall was reached. The deposit was cross-cut from the production drift. The production started in the cross-cut that was the closest to the back-wall, by drilling a fan-like pattern of boreholes, reaching the ore above and at the back. The ore, being of poorer mechanical properties than the hanging-wall, fell granulated towards the open space. As the ore was hauled towards the gravity chutes, the space in the cross-cut was emptied, and subsequently filled with granulated ore, until only waste rock from the hanging-wall and/or empty space remained. The crosscuts were mined subsequently, from back to front, until the whole level was mined. While production on the first level was still active, the preparation was ongoing in the second level. As the first level reached the end, the second level was already prepared for full production.

Sometimes, instead of two shafts, the deposit was vertically developed with a spiral ramp, enabling the use of diesel loaders and trucks. However, the height of one level $(7.5 \mathrm{~m})$ required $45 \mathrm{~m}$ of a spiral ramp (versus $15-$

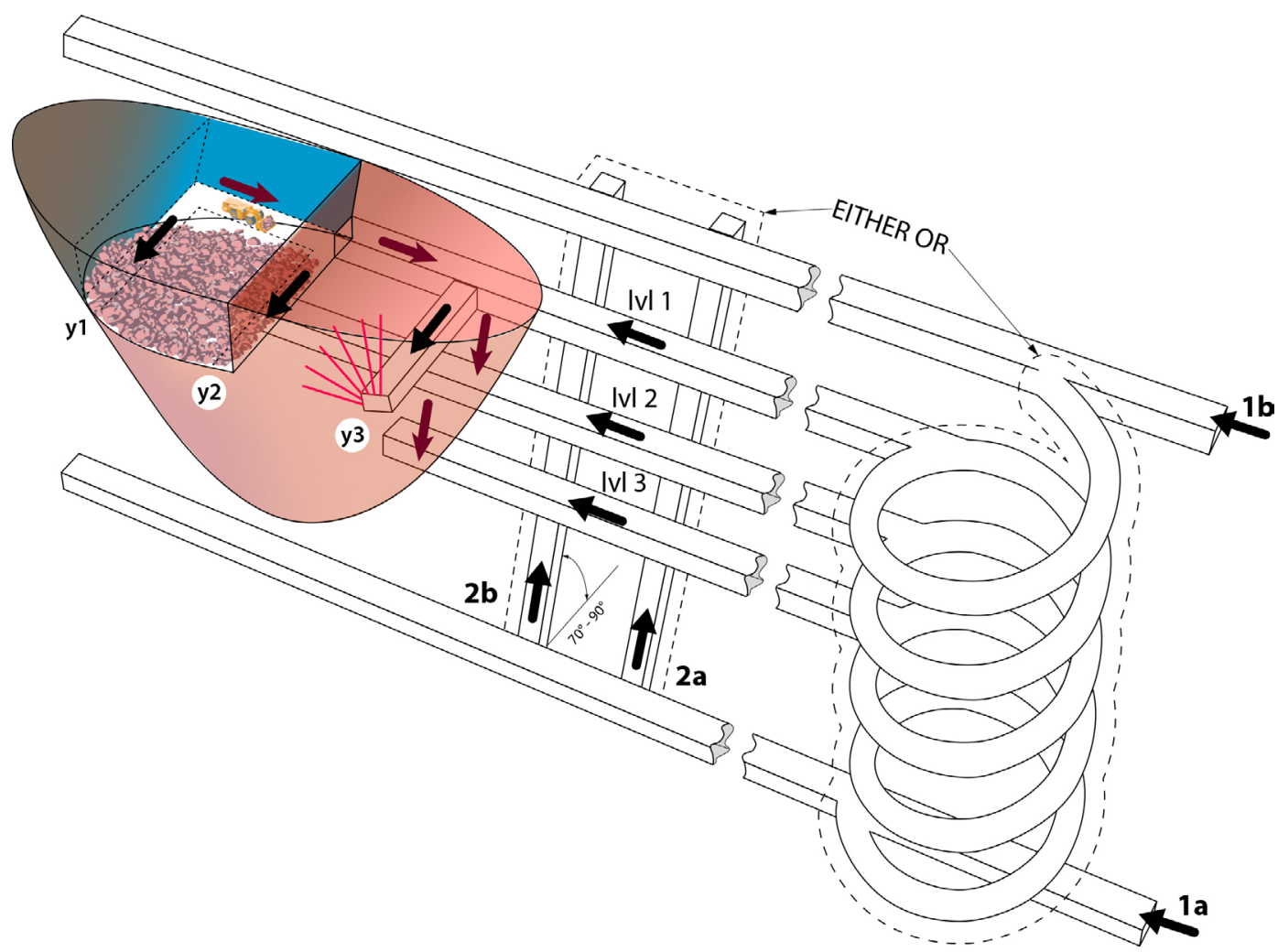

Figure 3. Typical variant of the sublevel caving method applied in the Bauxite Mines Jajce. Numeration follows the order of mining and the arrows are showing the direction of works (progression of the access and development, and progression of the ore extraction).

Access (in waste rock): 1a-main transport corridor (decline), $1 \mathrm{~b}$-main directional corridor (decline);

Development (in waste rock): $2 \mathrm{a}$ - shaft with chutes for gravity transport (raise) and $2 \mathrm{~b}$ - ventilation shaft (raise), or 3 - spiral ramp serving for both ore transport and ventilation; Production (in ore): lvlı..lvl3 - levels, $\mathrm{x}$-production drift, y1...y3 - cross-cuts. 
Table 4. Land use in the Bauxite Mines Jajce, by exploitation field and type of use/transformation (L-34 is part of the Bešpelj exploitation field, same as Bešpelj Mine, and although it is mined separately from the Bešpelj Mine, the area of the exploitation field is not partitioned).

\begin{tabular}{|c|c|c|c|c|}
\hline Land use / Exploitation field & Crvene Stijene & Poljane & $\begin{array}{l}\text { Bešpelj } \\
\text { (L-34 included) }\end{array}$ & $\begin{array}{l}\text { Bauxite Mines Jajce } \\
\text { (total) }\end{array}$ \\
\hline Transformed $\left(\mathrm{m}^{2}\right)$ & $\begin{array}{l}44625 \\
(6.4 \%)\end{array}$ & $\begin{array}{l}103292 \\
(6.2 \%)\end{array}$ & $\begin{array}{l}81611 \\
(5.6 \%)\end{array}$ & $\begin{array}{l}147917 \\
(6.0 \%)\end{array}$ \\
\hline - buildings $\left(\mathrm{m}^{2}\right)$ & 784 & 510 & 311 & 1294 \\
\hline - roads $\left(\mathrm{m}^{2}\right)$ & 26651 & 31720 & $\begin{array}{l}36647 \\
\left(7282 \mathrm{~m}^{2} \text { for } \mathrm{L}-34\right)\end{array}$ & 58371 \\
\hline - open pits $\left(\mathrm{m}^{2}\right)$ & 0 & 18690 & 28158 & 18690 \\
\hline - ore storage plateau $\left(\mathrm{m}^{2}\right)$ & 15990 & 38637 & 10050 & 54627 \\
\hline - sinkholes $\left(\mathrm{m}^{2}\right)$ & 1200 & 13735 & $\begin{array}{l}6445 \\
\left(5925 \mathrm{~m}^{2} \text { at L-34) }\right.\end{array}$ & 14935 \\
\hline Natural (forest and agricultural) $\left(\mathrm{m}^{2}\right)$ & $\begin{array}{l}650375 \\
(93.6 \%)\end{array}$ & $\begin{array}{l}1554708 \\
(93.8 \%)\end{array}$ & $\begin{array}{l}1368389 \\
(94.4 \%)\end{array}$ & $\begin{array}{l}2205083 \\
(94.0 \%)\end{array}$ \\
\hline Total, transformed and natural $\left(\mathrm{m}^{2}\right)$ & $\begin{array}{l}695000 \\
(18 \%)\end{array}$ & $\begin{array}{l}1658000 \\
(44 \%)\end{array}$ & $\begin{array}{l}1450000 \\
(38 \%)\end{array}$ & $\begin{array}{l}3803000 \\
(100 \%)\end{array}$ \\
\hline
\end{tabular}

$20 \mathrm{~m}$ of raise per level), requiring more development in the waste rock.

\subsection{System description}

\subsubsection{Land use and permissions}

Underground mining of bauxite in Bosnia and Herzegovina requires a land concession for mining from the government. The concession contract stipulates that the mine must obtain clearance from other landowners, either by land purchase or by a land use contract. Thus, every exploitation field for an underground mine can include different types of land ownership (governmental, private, mine). The land use in the Bauxite Mines Jajce is mainly maintained as it was before the mining concession $-94 \%$ of the land remained unchanged (grassland, forest, and karst terrain). If a mine needs the land (within the concession field) for an open pit mine, access roads, buildings, exploration, etc., it is necessary to obtain agreement from the landowner and possibly ownership. If land sinking occurs due to the caving of the underground space, the practice is to compensate the landowner and possibly buy the land. The sink holes are used for the disposal of waste rock (stripped material) from the dimension stone quarries when near or fenced and marked with signs to prevent the falling of people and animals.

Currently, there are 6 sinkholes related to shallow ore deposits. They were all planned and created during ore extraction from the first levels. Until now, there were no accidents related to the sinkholes. Table 4 shows the detailed specification of the land area and its use.

\subsubsection{Labour}

The Bauxite Mines Jajce had 126 employees in the mines on average (standard deviation of sample equals 8): 40 in the Crvene Stijene Mine (st.dev. =7); 41 in the
Table 5. Mass balance of the blasting and calculated emission factors

\begin{tabular}{|c|c|c|c|}
\hline Detonator & $(g / p c)$ & Emission & g/pc \\
\hline $\begin{array}{l}\text { Detonator } \\
\text { (one piece weighted) }\end{array}$ & 1.73 & $\mathrm{~Pb}$ & 0.1423 \\
\hline - Aluminium casing & 0.73 & $\mathrm{Al}$ & 0.7300 \\
\hline - Lead azide $\mathrm{Pb}\left(\mathrm{N}_{3}\right)_{2}$ & 0.20 & $\mathrm{~N}_{2}^{*}$ & 0.1996 \\
\hline \multirow[t]{3}{*}{ - Penthrite $\mathrm{C}_{5} \mathrm{H}_{8} \mathrm{~N}_{4} \mathrm{O}_{12}$} & 0.80 & $\mathrm{CO}_{2}^{*}$ & 0.5569 \\
\hline & & $\mathrm{H}_{2} \mathrm{O}$ & 0.6682 \\
\hline & & $\mathrm{O}_{2}$ & $-0.5669 * *$ \\
\hline Explosives & $(\mathrm{kg})$ & Emission & $\mathrm{kg} / \mathrm{kg}$ \\
\hline Assumed composition & 1.00 & $\mathrm{H}_{2} \mathrm{O}$ & 1.5567 \\
\hline $\begin{array}{l}\text { - Nitroglycol } \\
\text { (ethylene glycol } \\
\text { dinitrate (EGDN,NGc) } \\
\mathrm{C}_{2} \mathrm{H}_{4}(\mathrm{ONO})_{2}\end{array}$ & 0.20 & $\mathrm{CO}_{2}^{*}$ & 0.2735 \\
\hline $\begin{array}{l}\text { - Ammonium nitrate } \\
\mathrm{NH}_{4} \mathrm{NO}_{3}\end{array}$ & 0.70 & $\mathrm{KNO}_{2}$ & 0.0421 \\
\hline $\begin{array}{l}\text { - Potassium nitrate } \\
\mathrm{KNO}_{3}\end{array}$ & 0.05 & $\mathrm{~N}_{2}^{*}$ & 0.2918 \\
\hline $\begin{array}{l}\text { - Cellulose }\left(\mathrm{C}_{6} \mathrm{H}_{10} \mathrm{O}_{5}\right) n \\
\text { - as cardboard }\end{array}$ & 0.02 & $\mathrm{O}_{2}$ & $-1.1641 * *$ \\
\hline - Diesel $\left(\mathrm{C}_{12} \mathrm{H}_{24}\right)$ & 0.03 & & \\
\hline $\begin{array}{l}\text { Electrical cable for } \\
\text { blasting (Ereiz, 2019: } \\
0.26 \text { m /detonator) }\end{array}$ & $(\mathrm{g} / \mathrm{m})$ & Emission & $\mathrm{g} / \mathrm{m}$ \\
\hline $\begin{array}{l}\text { Double PVC-insulated } \\
\text { copper wire }\end{array}$ & 17.56 & & \\
\hline - Conductor wire $(\mathrm{Cu})$ & 5.07 & $\mathrm{Cu}$ & 5.07 \\
\hline - $\mathrm{PVC}$ insulation & 12.49 & PVC & 12.49 \\
\hline
\end{tabular}

* Stoichiometry is valid when the oxygen availability is optimal, otherwise NOx and CO can be expected as well. Some $\mathrm{N}_{2}$ should be recalculated as $\mathrm{NOx}$, and $\mathrm{CO}_{2}$ as $\mathrm{CO}$

** negative value of oxygen - oxygen input (from air) to satisfy stoichiometric balance. 
Table 6. Mechanization by mine, type of operations, and fuel use

\begin{tabular}{|l|l|l|l|l|l|}
\hline Mechanization type / Mine & Crvene Stijene & Poljane & Bešpelj & L-34 & $\begin{array}{l}\text { Bauxite Mines Jajce } \\
\text { (total) }\end{array}$ \\
\hline Load and haul (air) & 3 & 4 & 5 & 1 & 13 \\
\hline Underground transport (electricity) & 1 & 3 & 3 & - & 7 \\
\hline Load and haul (diesel) & 1 & - & 1 & 1 & 3 \\
\hline Underground transport (diesel) & 1 & - & - & 1 & 2 \\
\hline Earthworks/ load and haul at surface (diesel) & 1 & - & 1 & - & 2 \\
\hline
\end{tabular}

Poljane Mine (st. dev. = 3); 39 in the Bešpelj-Poljane Mine (st. dev. =5), and 8 in the L-34 Mine (st.dev. =2). The inventory shows average man-day values for each mining site, including sick leave and paid vacations.

\subsubsection{Blasting}

The industrial explosive Vitezit V-20 used in blasting operations is a plastic emulsion ammonium nitrate type, locally produced in the town of Vitez ( $80 \mathrm{~km}$ distance). The explosive is initialized with an electric detonator (No.8 aluminium casing, lead-azide and penthrite charge). The electric connector (cable) is a PVC insulated double copper wire. The calculation of emissions from blasting, due to the unavailability of data, both in the database and in the product specification, required assumptions on the composition of explosives and the stoichiometry of blasting. These assumptions are based on professional literature and technical papers (Eržen and Sabioncello 1969; Orlović-Leko, 2013; URL3; URL4). The estimated composition of the explosive is $70 \%$ ammonium nitrate $\left(\mathrm{NH}_{4} \mathrm{NO}_{3}\right), 20 \%$ nitroglycol $\left(\mathrm{C}_{2} \mathrm{H}_{4}(\mathrm{ONO})_{2}\right), 5 \%$ sodium or potassium nitrate $\left(\left(\mathrm{NaNO}_{3}\right.\right.$ or $\left.\mathrm{KNO}_{3}\right), 3 \%$ diesel, and $2 \%$ cellulose $\left(\left(\mathrm{C}_{6} \mathrm{H}_{10 \mathrm{O}_{5}}\right) \mathrm{n}\right)$. The Mass of the detonator (one piece), as determined directly in the Laboratory for Testing Explosives (at the authors' institution) was 1.73 grams. The weight of the aluminium casing was 0.73 grams. The assumption on the explosive content was $0.20 \mathrm{~g}$ of lead azide, $\mathrm{Pb}\left(\mathrm{N}_{3}\right)_{2}$, and 0.8 grams of penthrite, $\mathrm{C}_{5} \mathrm{H}_{8} \mathrm{~N}_{4} \mathrm{O}_{12}$ (see Table 5).

The electrical cable used in the blasting was double PVC-insulated copper wire. A single copper wire was $0.6 \mathrm{~mm}$ in diameter. The diameter of a single insulated wire (copper and PVC) was $2.5 \mathrm{~mm}$.

\subsubsection{Mine support}

Locally supplied timber is used for the support system in the mine, for ladders, platforms, shafts, and shelters. The type of timber is softwood (pine) or mixed softwood and hardwood (beech), supplied from the local forest. The supply of the timber can be modelled as chain sawing and transport up to $10 \mathrm{~km}$ in distance.

\subsubsection{Mechanization: load and haul and mine transport}

Mechanization in the Jajce Mines, based on the type of energy, was divided into diesel, air, end electricity driven. The diesel fuel users were an underground loader $\mathrm{GHH}$, an underground truck, a surface loader, and an excavator. The mechanization on the surface is used mainly for road maintenance.

The electricity users were an electric battery (DC) locomotive, a ventilation fan, and a compressor station for compressed air. The compressed air is supplied to an underground loading shovel, a CAVO loader, and to pneumatic drills (quantity unspecified).

The mechanization inventory by type and fuel is given in Table 6. The load and haul mechanization by type of energy was 13:3 in favour of air loaders in the Bauxite Mines Jajce: 3:1 at Crvene Stijene, 4:0 at Poljane, 5:1 at Bešpelj, and 1:1 in L-34. Mine transport relied on the battery locomotive in all mines except in L-34, because it was quite distant from the main transport corridor of the Bešpelj Mine, so the development of a transport corridor separate from the main system was not rational.

\subsubsection{Maintenance}

Maintenance included the use of mineral oils and grease for different purposes, for lubrication of the heavy-duty machines such as the loader Cavo and the loading shovel, locomotive and wagons, drills, etc. The following list of oils and grease was made based on the diary of the foreman of the Bešpelj mine (L-34 included):

- "SAE (30, 15-40, 15-45)" motor oil. This oil is expected to be collected and recycled (consumed 66 $\mathrm{dm}^{3}$ at Bešpelj 2010-2012);

- "Hipenol 90" oil for heavy duty transmission (consumed $476 \mathrm{dm}^{3}$ at Bešpelj 2010-2012);

- "Polar" oil for pneumatic tools and engines (consumed $3707 \mathrm{dm}^{3}$ at Bešpelj 2010-2012);

- "Hidrol" hydraulic oil (consumed $106 \mathrm{dm}^{3}$ at Bešpelj 2010-2012);

- "Tot-mast" multipurpose mineral grease for lubrication of bearings and so on (consumed $126 \mathrm{~kg}$ $\approx 158 \mathrm{dm}^{3}$ at Bešpelj 2010-2012). This data was first presented in conference (Grbeš et al. 2018).

The above shown quantities (total $4513 \mathrm{dm}^{3}$ ) do not necessarily equal to the total consumed oils and grease in the Bešpelj mine and the L-34 site in the period 20102012 because a certain quantity must be stored and be available at the site. However, it is expected that this 
Table 7. Inventory of bauxite mining in the Bauxite Mines Jajce during the period 2010-2020 (total mass)

\begin{tabular}{|c|c|c|c|c|c|}
\hline $\begin{array}{l}\text { MINE/ } \\
\text { 11-YEAR INVENTORY }\end{array}$ & Crvene Stijene & Poljane & Bešpelj & L-34 & $\begin{array}{l}\text { Bauxite Mines Jajce } \\
\text { (total) }\end{array}$ \\
\hline Production $(\mathrm{t})$ & $\begin{array}{l}375269 \\
(31 \%)\end{array}$ & $\begin{array}{l}368001 \\
(30 \%)\end{array}$ & $\begin{array}{l}379341 \\
(31 \%)\end{array}$ & $\begin{array}{l}106835 \\
(9 \%)\end{array}$ & $\begin{array}{l}1229446 \\
(100 \%)\end{array}$ \\
\hline Length of development (m) & $\begin{array}{l}3960 \\
(34 \%)\end{array}$ & $\begin{array}{l}3989 \\
(34 \%)\end{array}$ & $\begin{array}{l}3300 \\
(28 \%)\end{array}$ & $\begin{array}{l}519 \\
(4 \%)\end{array}$ & $\begin{array}{l}11768 \\
(100 \%)\end{array}$ \\
\hline Waste rock $\left(\mathrm{m}^{3}\right)$ & 23760 & 23934 & 19800 & 3114 & 70608 \\
\hline Labour (man-day) & $\begin{array}{l}113501 \\
(33 \%)\end{array}$ & $\begin{array}{l}104216 \\
(30 \%)\end{array}$ & $\begin{array}{l}113144 \\
(33 \%)\end{array}$ & $\begin{array}{l}16585 \\
(5 \%)\end{array}$ & $\begin{array}{l}347446 \\
(100 \%)\end{array}$ \\
\hline Electricity (kWh) & $\begin{array}{l}6384864 \\
(37 \%)\end{array}$ & $\begin{array}{l}5089078 \\
(30 \%)\end{array}$ & $\begin{array}{l}4798241 \\
(28 \%)\end{array}$ & $\begin{array}{l}822851 \\
(5 \%)\end{array}$ & $\begin{array}{l}17095035 \\
(100 \%)\end{array}$ \\
\hline Energy from electricity (GJ) & 22986 & 18321 & 17274 & 2962 & 61542 \\
\hline $\operatorname{Diesel}\left(\mathrm{dm}^{3}\right)$ & $\begin{array}{l}304978 \\
(54 \%)\end{array}$ & $\begin{array}{l}25052 \\
(4 \%)\end{array}$ & $\begin{array}{l}111319 \\
(20 \%)\end{array}$ & $\begin{array}{l}123245 \\
(22 \%)\end{array}$ & $\begin{array}{l}564594 \\
(100 \%)\end{array}$ \\
\hline Energy from diesel (GJ) & 11589 & 952 & 4230 & 4683 & 21455 \\
\hline Energy, total (GJ) & $\begin{array}{l}34575 \\
(42 \%)\end{array}$ & $\begin{array}{l}19273 \\
(23 \%)\end{array}$ & $\begin{array}{l}21504 \\
(26 \%)\end{array}$ & $\begin{array}{l}7646 \\
(9 \%)\end{array}$ & 82997 \\
\hline Explosives (kg) & $\begin{array}{l}253246 \\
(35 \%)\end{array}$ & $\begin{array}{l}261738 \\
(36 \%)\end{array}$ & $\begin{array}{l}182444 \\
(25 \%)\end{array}$ & $\begin{array}{l}34996 \\
(5 \%)\end{array}$ & $\begin{array}{l}732424 \\
(100 \%)\end{array}$ \\
\hline Detonators (pcs) & $\begin{array}{l}251471 \\
(35 \%)\end{array}$ & $\begin{array}{l}242229 \\
(33 \%)\end{array}$ & $\begin{array}{l}189369 \\
(26 \%)\end{array}$ & $\begin{array}{l}41660 \\
16 \%)\end{array}$ & $\begin{array}{l}724729 \\
(100 \%)\end{array}$ \\
\hline Timber $\left(\mathrm{m}^{3}\right)$ & $\begin{array}{l}491 \\
(19 \%)\end{array}$ & $\begin{array}{l}938 \\
(36 \%)\end{array}$ & $\begin{array}{l}806 \\
(31 \%)\end{array}$ & $\begin{array}{l}385 \\
(15 \%)\end{array}$ & $\begin{array}{l}2620 \\
(100 \%)\end{array}$ \\
\hline Mineral oils (kg) & $\begin{array}{l}16912 \\
(32 \%)\end{array}$ & $\begin{array}{l}19014 \\
(35 \%)\end{array}$ & $\begin{array}{l}13788 \\
(26 \%)\end{array}$ & $\begin{array}{l}3942 \\
(7 \%)\end{array}$ & $\begin{array}{l}53656 \\
(100 \%)\end{array}$ \\
\hline
\end{tabular}

data shows sufficiently representative mass ratios of different types of lubricants in use:

- $1.5 \%$ motor oil;

- $10.5 \%$ heavy duty transmission oil;

- $82.0 \%$ mineral oil for pneumatic tools and engines;

- $2.3 \%$ hydraulic oi;

- $3.5 \%$ mineral grease.

\subsubsection{Energy}

Diesel fuel is used for mine mechanization, but it also used for shuttle transportation of miners. However, that data was not accounted, so the partition is not possible. Gasoline and motor oil are used for chain saws which are used for building mine support, however, they are not accounted in the mine inventories.

Compressed air is generated on the surface in a compressor and transported underground to compressor stations (tanks). The use of compressed air is facilitating aeration of the production tunnels. The electricity for the generation of compressed air accounts for $90-95 \%$ of the electricity consumed (estimated by the operations manager). Other users of electricity are locomotive battery (charging), ventilation fans, and lights/heating, mostly in facilities at the surface.

\subsubsection{Unaccounted and missing data}

Unaccounted data mainly refers to tools and hardware, personal lamps and protective clothes (protective gloves and rubber boots are consumed in greatest quantities), consumable parts of the drills, and tires. Unaccounted data could play an important role in environmental impacts, depending on the quantities and the waste scenario. An estimate in the LCA should at least be made for the most consumed products, such as gloves and boots.

\subsection{Inventory of bauxite production}

The main input data and information on production with quantities summed over the $2010-2020$ period is shown in Table 7, and detailed information is provided in the supplementary materials. Table $\mathbf{8}$ gives relative values of input for the production of $1 \mathrm{t}$ of bauxite. The previously shown Table 5 provides a balanced inputoutput analysis of blasting with emission factors, and Table 9 shows the calculated direct emissions from the analysed foreground system, namely from the blasting operations and diesel combustion in heavy duty off-road machinery.

Bauxite Mines Jajce (BMJ) produced $112 \cdot 10^{3}$ tons of bauxite per year on average and developed 1070 meters in length per year or $11768 \mathrm{~m}$ in the observed period (of which the main corridors constituted $41 \%$, sublevel/production drifts $33 \%$, shafts for ventilation and gravity transport $20 \%$, and the spiral ramp $6 \%$ ) on average. The specific contribution of each mine was as follows:

1. the Crvene Stijene Mine produced $34 \cdot 10^{3}$ tons of bauxite per year on average and developed 360 
Table 8. Inventory of mining $1 \mathrm{t}$ of bauxite in Bauxite Mines Jajce (relative values)

\begin{tabular}{|l|l|l|l|l|l|}
\hline MINE/INVENTORY & Crvene Stijene & Poljane & Bešpelj & L-34 & Bauxite Mines Jajce \\
\hline Production $(\mathrm{t} / \mathrm{t})$ & 1 & 1 & 1 & 1 & 1 \\
\hline Length of development $(\mathrm{m} / \mathrm{t})$ & 0.010552 & 0.010840 & 0.008699 & 0.004858 & 0.009572 \\
\hline $\begin{array}{l}\text { Waste rock } \\
\left(\mathrm{m}^{3} / \mathrm{t}\right)\end{array}$ & 0.063315 & 0.065038 & 0.052196 & 0.029148 & 0.057431 \\
$(\mathrm{t} / \mathrm{t})$ & 0.170949 & 0.175602 & 0.140929 & 0.078699 & 0.155063 \\
\hline Labour $(\mathrm{man}-$ day/t) & 0.302452 & 0.283195 & 0.298265 & 0.155239 & 0.282604 \\
\hline Electricity $(\mathrm{kWh} / \mathrm{t})$ & 17.014 & 13.829 & 12.649 & 7.702 & 13.905 \\
\hline Energy from electricity $(\mathrm{MJ} / \mathrm{t})$ & 61.251 & 49.784 & 45.536 & 27.727 & 50.057 \\
\hline Diesel $(\mathrm{dm} / \mathrm{t})$ & 0.812692 & 0.068076 & 0.293454 & 1.153601 & 0.459226 \\
\hline Energy from diesel $(\mathrm{MJ} / \mathrm{t})$ & 30.882 & 2.587 & 11.151 & 43.837 & 17.451 \\
\hline Energy, total $(\mathrm{MJ} / \mathrm{t})$ & 92.133 & 52.371 & 56.687 & 71.564 & 67.507 \\
\hline Explosives $(\mathrm{kg} / \mathrm{t})$ & 0.674839 & 0.711243 & 0.480950 & 0.327571 & 0.595735 \\
\hline Detonators $(\mathrm{pcs} / \mathrm{t})$ & 0.670109 & 0.658229 & 0.499205 & 0.389947 & 0.589476 \\
\hline Timber $\left(\mathrm{m}^{3} / \mathrm{t}\right)$ & 0.001308 & 0.002549 & 0.002125 & 0.003604 & 0.002131 \\
\hline Mineral oils $(\mathrm{kg} / \mathrm{t})$ & 0.045066 & 0.051668 & 0.036347 & 0.036898 & 0.043642 \\
\hline
\end{tabular}

Table 9. Inventory of mining $1 \mathrm{t}$ of bauxite in the Bauxite Mines Jajce (relative values) - direct emissions: emissions from blasting and diesel combustion (Tier 1 emission factors for heavy duty diesel vehicles from Tables 3.5-3.15 in the EMEP/EEA air pollutant emission inventory guidebook 2016)

\begin{tabular}{|c|c|c|c|c|c|c|}
\hline Emission & Emission factor & Crvene Stijene & Poljane & Bešpelj & L-34 & $\begin{array}{r}\text { Bauxite Mines } \\
\text { Jajce }\end{array}$ \\
\hline Detonator & $\mathrm{g} / \mathrm{pc}$ detonator & & & & & \\
\hline $\mathrm{Pb}(\mathrm{g})$ & 0.142300 & 0.095 & 0.094 & 0.071 & 0.055 & 0.084 \\
\hline $\mathrm{Al}(\mathrm{g})$ & 0.730000 & 0.489 & 0.481 & 0.364 & 0.285 & 0.430 \\
\hline $\mathrm{N}_{2}^{*}(\mathrm{~g})$ & 0.199600 & 0.134 & 0.131 & 0.100 & 0.078 & 0.118 \\
\hline $\mathrm{CO}_{2} *(\mathrm{~g})$ & 0.556900 & 0.373 & 0.367 & 0.278 & 0.217 & 0.328 \\
\hline $\mathrm{H}_{2} \mathrm{O}(\mathrm{g})$ & 0.668200 & 0.448 & 0.440 & 0.334 & 0.261 & 0.394 \\
\hline $\mathrm{O}_{2}(\mathrm{~g})$ & -0.566900 & -0.380 & -0.373 & -0.283 & -0.221 & -0.334 \\
\hline Explosives & $\mathrm{g} / \mathrm{kg}$ explosives & & & & & \\
\hline $\mathrm{H}_{2} \mathrm{O}(\mathrm{g})$ & 1556.7 & 1050.521 & 1107.191 & 748.695 & 509.929 & 927.381 \\
\hline $\mathrm{CO}_{2}^{*}(\mathrm{~g})$ & 273.5 & 184.568 & 194.525 & 131.540 & 89.591 & 162.934 \\
\hline $\mathrm{KNO}_{2}(\mathrm{~g})$ & 42.1 & 28.411 & 29.943 & 20.248 & 13.791 & 25.080 \\
\hline $\mathrm{N}_{2}^{*}(\mathrm{~g})$ & 291.8 & 1050.521 & 1107.191 & 748.695 & 509.929 & 927.381 \\
\hline $\mathrm{O}_{2}(\mathrm{~g})$ & -1164.1 & -785.580 & -827.958 & -559.874 & -381.325 & -693.495 \\
\hline Diesel & $\mathrm{g} / \mathrm{kg}$ fuel & & & & & \\
\hline $\mathrm{CO}_{2}(\mathrm{~g})$ & 3180.00 & 2196.705654 & 184.009163 & 793.205209 & 3118.184443 & 1241.288826 \\
\hline $\mathrm{NO}_{\mathrm{x}}(\mathrm{g})$ & 33.37 & 23.051594 & 1.930939 & 8.323666 & 32.721325 & 13.025726 \\
\hline $\mathrm{CO}(\mathrm{g})$ & 7.58 & 5.236173 & 0.438613 & 1.890722 & 7.432653 & 2.958795 \\
\hline $\mathrm{CO}_{2}$ from lubricant $(\mathrm{g})$ & 2.54 & 1.754601 & 0.146976 & 0.633566 & 2.490625 & 0.991470 \\
\hline NMVOC $(g)$ & 1.92 & 1.326313 & 0.111100 & 0.478916 & 1.882677 & 0.749457 \\
\hline $\mathrm{PM}(\mathrm{g})$ & 0.94 & 0.649341 & 0.054393 & 0.234469 & 0.921727 & 0.366922 \\
\hline $\mathrm{f}-\mathrm{BC}, 0.53(\mathrm{~g})$ & 0.50 & 0.344151 & 0.028828 & 0.124269 & 0.488516 & 0.194469 \\
\hline $\mathrm{N}_{2} \mathrm{O}(\mathrm{g})$ & 0.05 & 0.035230 & 0.002951 & 0.012721 & 0.050009 & 0.019907 \\
\hline $\mathrm{SO}_{2}(\mathrm{~g})$ & 0.02 & 0.011053 & 0.000926 & 0.003991 & 0.015689 & 0.006245 \\
\hline $\mathrm{NH}_{3}(\mathrm{~g})$ & 0.013 & 0.008980 & 0.000752 & 0.003243 & 0.012747 & 0.005074 \\
\hline $\mathrm{Pb}(\mathrm{g})$ & 0.000052 & 0.000036 & 0.000003 & 0.000013 & 0.000051 & 0.000020 \\
\hline PAHs (g) & 0.0000782 & 0.000054 & 0.000005 & 0.000020 & 0.000077 & 0.000031 \\
\hline
\end{tabular}




\section{Life cycle inventory of mining one deposit: mining the bauxite from L-34 deposit in Bauxite Mines Jajce (2010-2018)}

Mine development and ore production

Production (t) $\quad \longrightarrow$ Waste rock (m3)

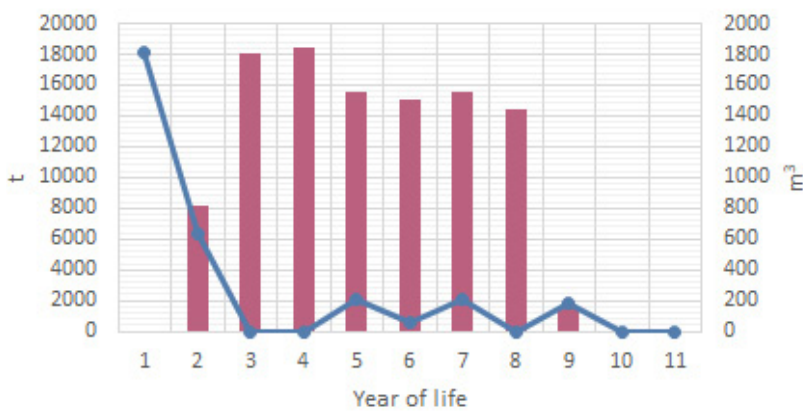

Energy

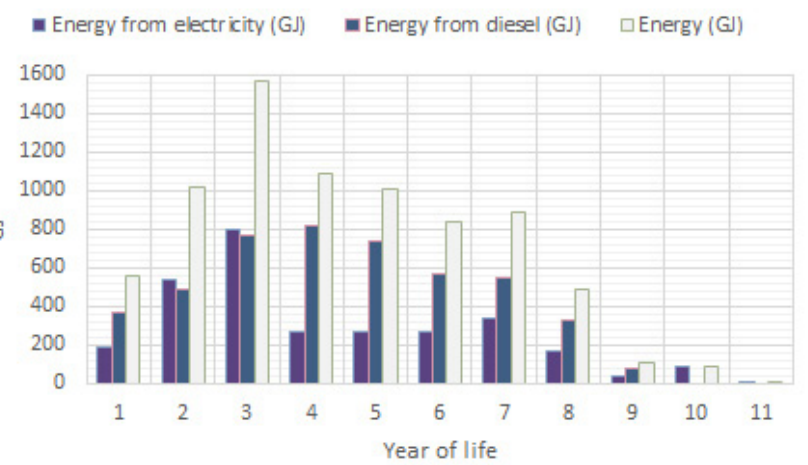

Maintenance of the mechanization

mineral oils $(\mathrm{kg})$

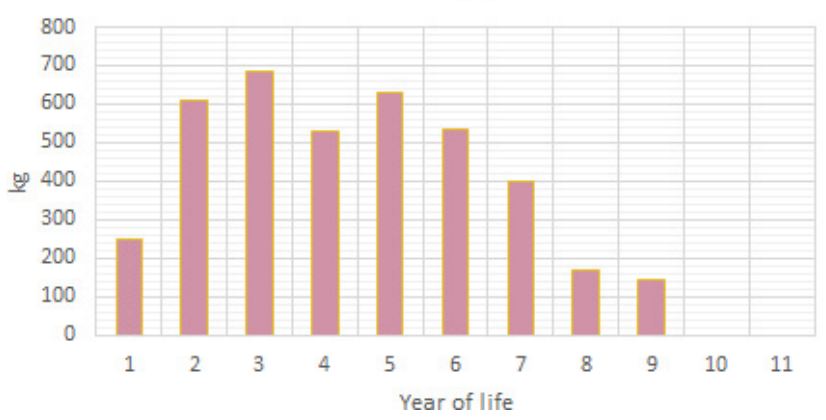

Labor

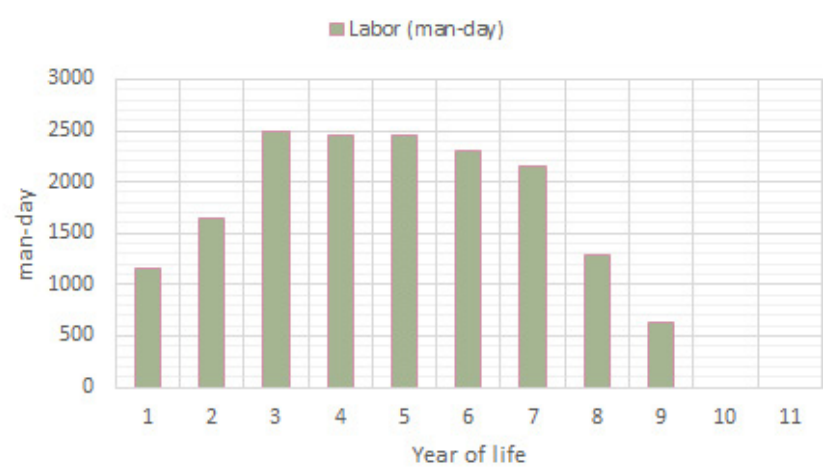

Blasting

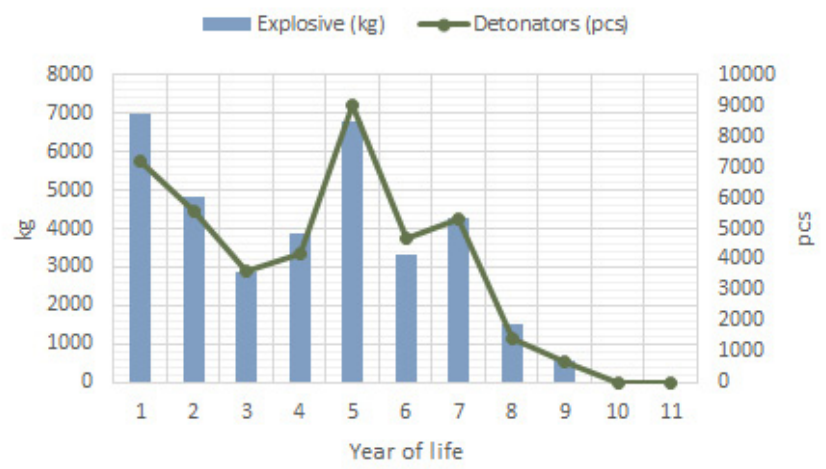

Mine support

- Timber $(\mathrm{m} 3)$

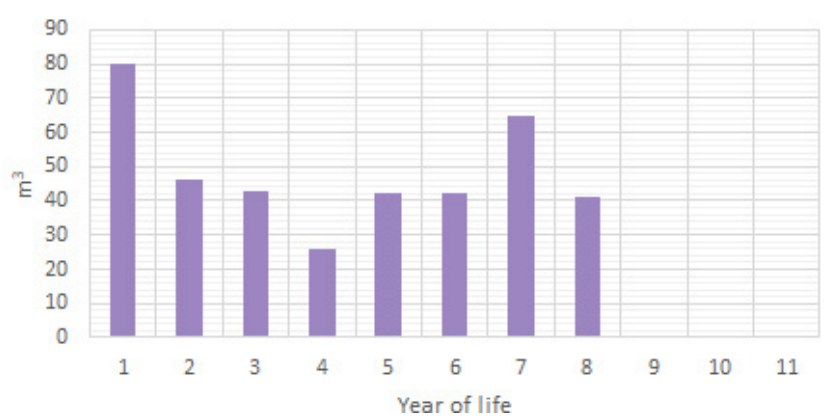

Figure 4. Life cycle inventory of mining one deposit: Mining the bauxite from the L-34 deposit in the Bauxite Mines Jajce (2010-2018). Graphs show: Mine development (m/y) and ore production (t/y); Labour (man-day/y); Energy (GJ/y); Blasting (explosive in $\mathrm{kg} / \mathrm{y}$ and detonators in pcs/y); Maintenance of the mechanization (consumption of mineral oils in $\mathrm{kg} / \mathrm{y}$ ); Mine support (consumption of timber in $\mathrm{m}^{3} / \mathrm{y}$ )

meters in length per year or $3960 \mathrm{~m}$ in the observed period (of which main corridors constitute $46 \%$, sublevel/production drifts $29 \%$, shafts for ventilation and gravity transport $17 \%$, and the spiral ramp $8 \%$ ) on average;

2. the Poljane Mine produced $33 \cdot 10^{3}$ tons of bauxite per year on average and developed 363 meters in length per year or $3989 \mathrm{~m}$ in the observed period (of which main corridors constitute $38 \%$, sublevel/pro- duction drifts $36 \%$, shafts for ventilation and gravity transport $20 \%$, and the spiral ramp $6 \%$ ) on average;

3. the Bešpelj-Pećine Mine produced $34 \cdot 10^{3}$ tons of bauxite per year on average and developed 300 meters in length per year or $3300 \mathrm{~m}$ in the observed period (of which main corridors constitute $43 \%$, sublevel/production drifts $31 \%$, shafts for ventilation and gravity transport $21 \%$, and the spiral ramp $5 \%$ ) on average; 


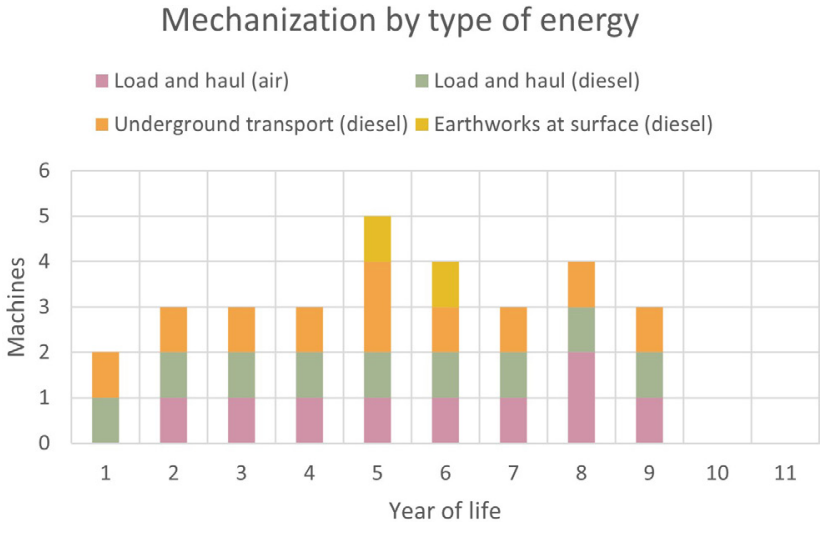

Figure 5. Mechanization by type and energy in the L-34 deposit of the Bauxite Mines Jajce (2010-2018)

4. the L-34 Mine produced $12 \cdot 10^{3}$ tons of bauxite per year on average and developed 58 meters in length per year or $519 \mathrm{~m}$ in the observed period (of which main corridors constitute $27 \%$, sublevel/production drifts $51 \%$, shafts for ventilation and gravity transport $20 \%$, and the spiral ramp $5 \%$ ) on average.

The three mines (Crvene Stijene, Poljane and BešpeljPećine) produced an average similar mass of ore in the observed period, however, in Bešpelj-Pećine Mine, due to less development in waste rock, the share in the consumption of the energy and materials was lower than the share in ore production. Poljane Mine, relying exclusively on the electricity and compressed air had overall the smallest consumption of energy (see Tables 7-8).

\subsection{A life cycle inventory of one deposit}

Mining the deposit L-34, due to its allocation from the Bešpelj-Pećine Mine, enabled separate accounting. This allowed insight into the complete mine life - from the opening phase in 2010 until its closure in 2018 (nine years in total). Exploration activities, which continued for a year or so, resulted in the consumption of electricity due to the use of the electrical drill.

The first year in mine life had the highest volume of waste rock in the overall mine life: $58 \%$ of waste rock was produced within the first year; $79 \%$ within the first two years. The production of ore started in the second year, reaching and maintaining high production from the third until before the final year. The time-series of mining and development was consistent with the description of the mining method. (see Figure 4, graph: Mine development and ore production). Blasting operations were the most intense at the beginning and in the middle of mine life (see Figure 4, graph: Blasting). When compared with the previous graph and the mining method, this is consistent with the access and development works.

The energy consumption was the highest in the third year, due to the intense use of air driven load and haul machines, however, the data for the next three years (46) was missing, and the average was used first (see Figure 4, graph: Energy). Since the same type and number of machines was used (see Figure 5) both in year 3 and 4 , and in those years the production of bauxite was the highest overall, it should be assumed that the consumption of electricity in year 4 was the same, if not higher than in the previous year.

The use of mechanization (see Figure 5) shows that underground transport apparently intensified in year 5, as well as the works on the surface, however, without indicating an increase in the consumption of energy from diesel.

Mine support activities required timber during the entire mine life, however, the highest use of timber was in the first and in the seventh year. In the final year, those activities ceased, however, probably only supply ceased while the remaining stocks from the previous year were used. However, that does not change the volume of the used timber (see Figure 4, graph: Mine support).

Machines for load and haul operations in difficult environments (dust, humidity, load, friction) require a lot of mineral oils (especially mineral grease). Three machines in years 2-4 consumed 500-700 kg of oils and grease per year, or $167-233 \mathrm{~kg}$ per machine annually. The Maintenance graph in Figure 4, shows similar behaviours as the graph of ore production, indicating that the load and haul operations are the main users. However, drilling of both the exploratory boreholes and boreholes for blasting was not specially accounted, so the amount of mineral grease allocated for those activities remains unclear.

Finally, all operations required labour. The most documented data available was on the number of employees and total labour in man-days, with paid vacations and sick leave included. The graph of Labour in Figure 4 is obviously showing similar trends as the production of ore and the maintenance of mechanization.

\section{Discussion}

Working with raw materials is a complex, creative and iterative, continuous process, of permitting, exploration, design, and adaptation to the variability of the nature, market (price-demand), and different constraints (Basu and Van Zyl, 2006; Stewart and Petrie, 2006). Relative values of labour, energy, and material intensity of ore production, as shown in this study (see Figure 6 -7), vary between the mines and within the same mine with time, however, on the company level, those intensities tend to remain stable within narrow intervals. This can be attributed to the mining method, mine planning, and the geology of Dinaric Alp-type bauxites. In the first year or two in the life of one deposit, the mining method dominantly focused on access and development works (see Figure 4), however, the geology and mine planning allow mine operations in multiple deposits, enabling scheduled and stable production.

If the function of the system is the mass of produced ore within some period of operation of one site, usually a year, as shown in Bongono et al. (2020), a too narrow 


\section{Life cycle inventory of unerground mining of bauxite in the Bauxite Mines Jajce: Annual variations of the relative inputs in period $2010-2020$}
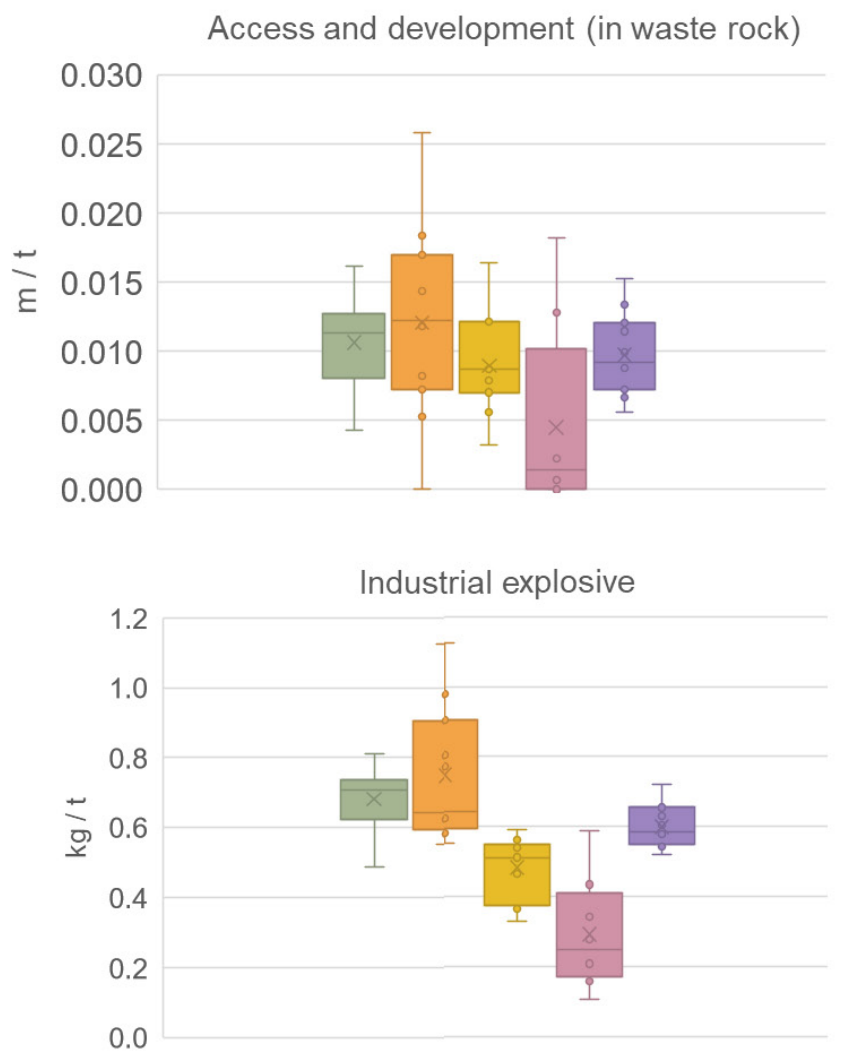

Timber

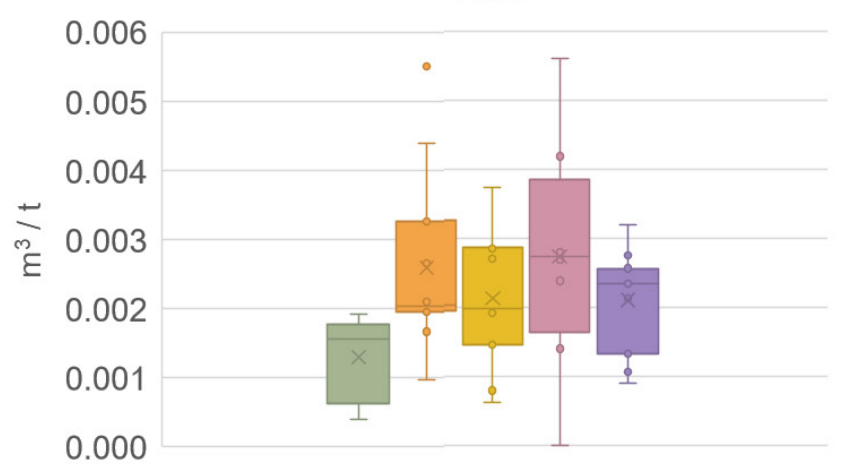

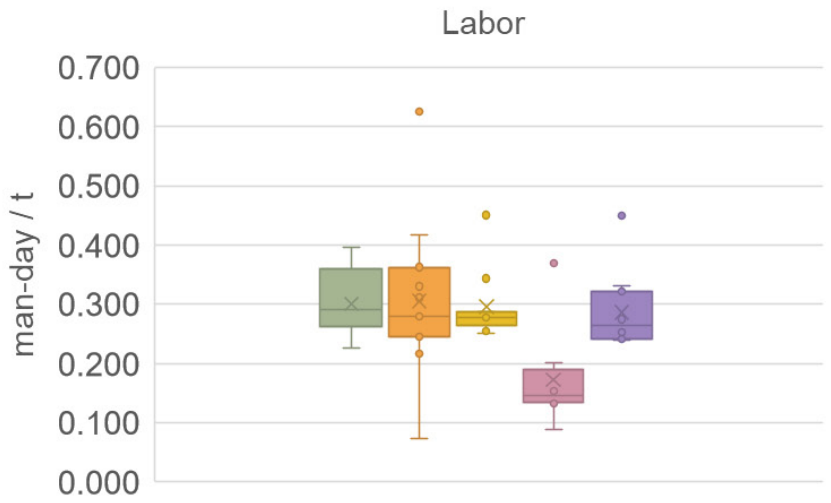
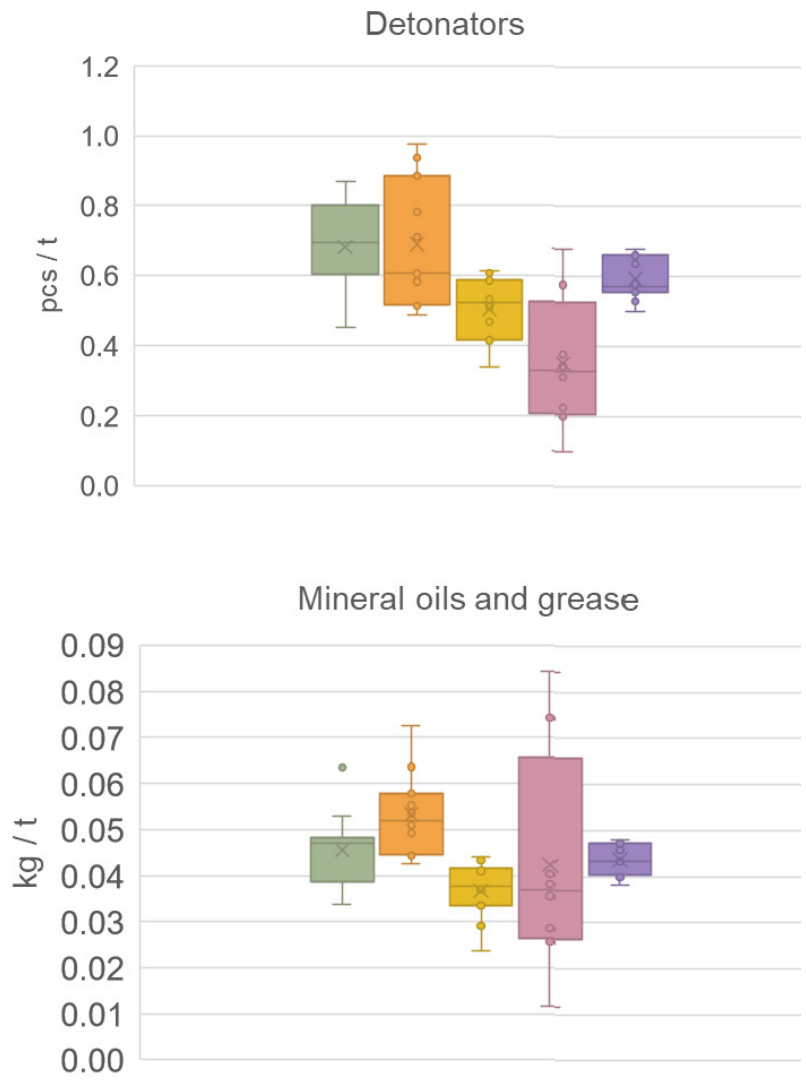

$\square$ Crvene Stijene $\square$ Poljane $\square$ Bešpelj-Pećine $\square$ L-34 $\square$ ALL

Figure 6. Annual variations of life cycle inventory in the Bauxite Mines Jajce in the period 2010-2020. The graphs show relative values: Mine development (m/t); Labour (man-day/t); Blasting (explosive in $\mathrm{kg} / \mathrm{t}$ and detonators in pcs/t); Maintenance of the mechanization (consumption of mineral oils in $\mathrm{kg} / \mathrm{t}$ ); Mine support (consumption of timber in $\mathrm{m}^{3} / \mathrm{t}$ )

reference period can result in environmentally expensive ore. In this study, in the first year of mining, errors in calculations occurred for the deposit L-34 when no ore was mined (division with zero). To avoid the errors and to integrate average environmental "costs" of the extracted ore, as shown in this study, when possible, the relative values should be calculated from longer periods (as in this paper). Optionally, some small quantity of ore can be "borrowed" to the non-productive year from the next year, to avoid division with zero. Another option can be to change the functional unit to mass of mined materials (both ore and waste rock); however, the utilization of such a functional unit might be relevant to a limited number of experts. 


\section{Life cycle inventory of underground mining of bauxite in the Bauxite Mines Jajce: Annual variations of relative energy inputs in period 2010-2020}

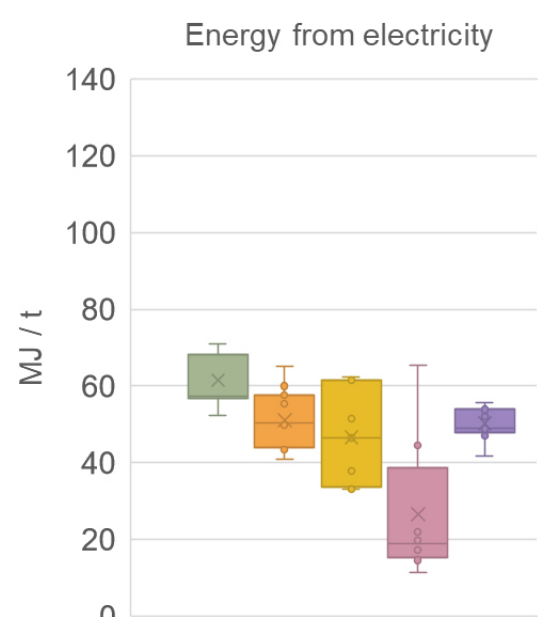

0

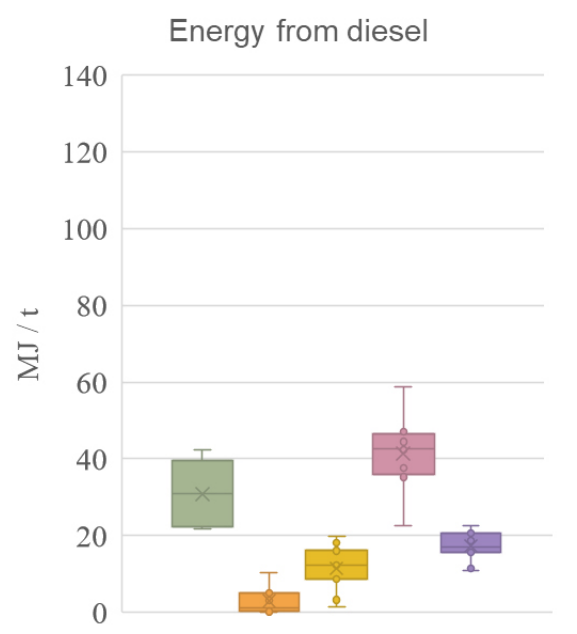

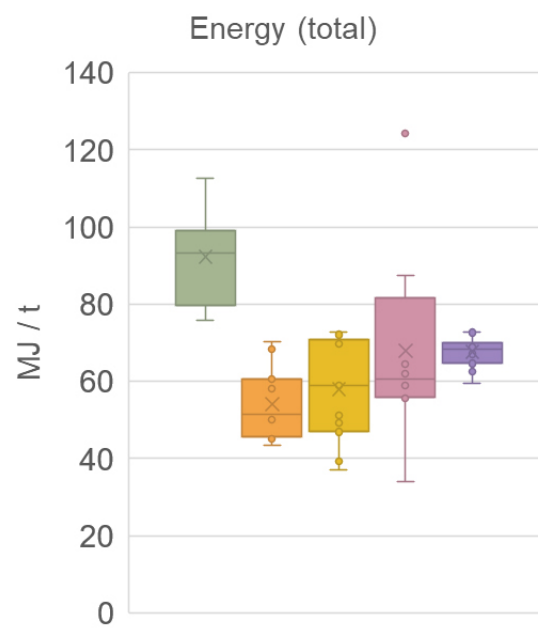

\section{$\square$ Crvene Stijene $\square$ Poljane $\square$ Bešpelj-Pećine $\square$ L-34 $\square$ ALL}

Figure 7. Annual variations of life cycle inventory in the Bauxite Mines Jajce in the period 2010-2020. The graphs show relative values of energy by source and total (in MJ/t)

Supply of the market with raw materials tends to become more systematized and easier to model down the stream/chain - transport, metallurgy, manufacture, etc. Metallurgical processes can be modelled and calculated with acceptable reliability, using engineering handbooks and publicly available information on processes, energy, equipment, and materials (Ayres 1995). The design of the mine operations should, however, rely on accounted data, mine design, and planning or at least on engineering estimates based on the previous experiences with the ore/deposit type and the mine design for similar contexts. The soundness of the LCA model of the mine and processing operations, while relying only on handbooks and public information, must be at least confirmed by the mining engineer. The current LCA practice, however, relies on secondary data from databases, and the modelling can fail due to the use of secondary data for industrial explosives, which is not recommended for use if the use of explosives is significant in process contribution (Ereiz, 2019). Since most of the product LCA starts with the raw material extraction as the first stage of the product life cycle, we find that the transparency and reliability of the LCA data on raw materials extraction, especially the life cycle inventory, should be recognized as an interest toward the climate neutrality goal. Mining LCAs should rely on original mining data as measured/ planned data and allow sufficiently reliable LCI modelling of similar contexts.

The life cycle inventory of an underground mine varies with the phase of mine life. The extraction of ore from small deposits can be planned with balanced production (outputs) and consumption of inputs, allowing good utilization of versatile mechanization at different operations: exploration, opening, development, production, closure, and surface works (access road maintenance etc.). Underground mining is also energy intensive. When the relevance of depth is not included, underground mining of bauxite in small deposits in Bosnia and Herzegovina ranged between 52-92 MJ/t on average (versus $37 \mathrm{MJ} / \mathrm{t}$ in strip (open-pit) mining of bauxite in Italy) (Ciacci, 2014). At the same time, underground mining of bauxite caused only $5.6-6.4 \%$ of the transformation of natural land above the mines and deposits.

In recent studies, electricity consumption and blasting operations are found to be the main cause of environmental impact (Farjana et al., 2019; Kapmann et al. 2019) in the LCA of European cobalt extraction. However, when the energy sector is improved, it affects the environmental performance of mining. Care is advised if the use of electricity is lowered at the expense of increasing the use of diesel. The combustion of diesel fuel underground, due to the emission of gases and particulates, can affect the work environment and health, and environmental tools other than LCA could be more appropriate for that. However, electricity use can be beneficial at the site, depending on fossil fuel use and other types of power for electricity production, the effect can be regionally and globally adverse. When the energy sector of Bosnia and Herzegovina improves its environmental performances, it can lead to a decrease of environmental pressures from bauxite mining in Jajce, while maintaining air quality at the site.

The results of this study indicate that detonators and ammonium-nitrate explosives, due to their mass and type of emissions, can become an important source of environmental impact. The path of airborne emissions 
through the underground system should be further investigated, especially regarding lead and nitrous compounds. The environmental impacts of blasting are mainly attributed to the dispersion of metal particles; however, the dispersion depends on whether the ore is mined in an open pit or underground, and on the type of ore. It is unclear from the study on chrome ore whether the particulates are originating from the explosives and detonators or from the cobalt ore itself (Farjana et al., 2019). The mineral composition of bauxite and surrounding rock shows mostly carbonate and weathered minerals (in Chapter 3) which are free from heavy environmental pollutants such as chrome metal. The cited study on chrome ore relied on the data from databases, however, the authors recommend the use of original mining data instead.

The engineering estimate of emissions from the blasting performed in this study contribute to a better understanding of emissions related to the use of explosives and detonators, however, the emissions should be further measured, and the path of the pollutants should be researched. The study of Kapmann et al. (2019) focussed on the type of data sources and environmental impacts, however, the type of explosives and LCI in general did not allow insight into the system. However, the important recommendation from that study was to utilize existing data collection and reporting systems of the mining companies as the source of life cycle inventory, such as: external and internal reports, internal information system, estimations based on parameters from the internal information system, and direct correspondence with the staff.

Work undertaken in the REEBAUX project has shown the content of rare earth elements ranging from 0.4 to $1.6 \%$ in most of the analysed samples of bauxite residue (red mud) in Croatia, Montenegro, Slovenia, and Hungary (Tomašić, 2021). Although Bosnia and Herzegovina was not the focus of the project, Jajce was an important supplier of bauxite for Hungary. Based on that, it would be interesting to research the content of rare earth elements in Jajce bauxites.

\section{Conclusion}

The life cycle inventory of an underground mine varies with the phase of mine life. Extraction of ore from small deposits can be planned with balanced production (outputs) and consumption of inputs, allowing good utilization of versatile mechanization at different operations: exploration, opening, development, production, closure, and surface works (access road maintenance, etc.). Underground mining is energy intensive. When the relevance of depth is not included, underground mining of bauxite in small deposits in Bosnia and Herzegovina ranged between 52-92 MJ/t on average (versus $37 \mathrm{MJ} / \mathrm{t}$ in strip (open-pit) mining of bauxite in Italy). At the same time, underground mining of bauxite caused only
5.6-6.4\% of the transformation of natural land above the mines and deposits.

The choice of mechanisation and energy can directly affect energy intensity. At the same time, it can affect the quality of the working atmosphere, as well as the potential impacts underground. Current operations rely on electricity as the main source of energy for machines, which is favourable for the working atmosphere at the local level, although the energy efficiency is decreased by the use of compressed air as mechanical energy. At the country level, the impacts are dependent on the energy mix, which is still quite fossil fuel dependent. The non-energy raw materials industry would significantly benefit from cleaner energy in electricity production.

The results of this study indicate that detonators and ammonium-nitrate explosives, due to their mass and type of emissions, can become an important source of environmental impacts. The path of airborne emissions through the underground system should be further investigated, especially regarding lead and nitrous compounds.

In mining LCAs using historical or observed data, it is advised to carefully consider the life stage of the mine and the characteristics of the mining method, especially if only one deposit is mined. The use of secondary data from the LCA databases, especially datasets for industrial explosives, can be far from satisfactory when blasting is the main method of extraction.

The observation from literature research in preparation of this study was that it would be difficult to recommend specific innovation needs within the ore extraction system or its supply. However, from the data collection process in this study, it can be recommended to further consider research into the mining methods, energy concepts in mine operations (both generation and storage), innovation in blasting (detonators, explosives, connector, and blasting operation itself), in order to improve environmental performances and resource efficiency of ore extraction and perform rare earth element assays in the exploration phase.

\section{Acknowledgements}

Special thanks to Mr. Najim Vunić, the foreman in Bešpelj-mine, who provided us access to his diaries of production and readily shared his knowledge on mine life and operations.

Software and the Ecoinvent database used in the LCA study are funded within the project REEBAUX (EIT Raw Materials, 2018). This study is partially funded from our earnings in the project MIN-GUIDE Grant agreement ID: 689527 (Horizon 2020, 2016).

Our thanks to Professor dr. sc. Mario Dobrilović and his team in the Laboratory for Testing Explosives at our Institution, Faculty of Mining, Geology and Petroleum Engineering, Department for Mining Engineering and Geotechnics, at the University of Zagreb, who evaluated the soundness of our assumptions related to explosives. 
We are very grateful to the editors and our reviewer, whose honest and helpful comments led to the improvement of our research and this paper.

\section{Data permissions}

The Inventory in this research and the original mining data is published with the permission of the company Rudnici boksita Jajce o.d.d. and the main designer Professor dr. sc. Ivo Galić from the Faculty of Mining, Geology and Petroleum Engineering.

\section{References}

Awuah-Offei, K. and Adekpedjou, A. (2011): Application of life cycle assessment in the mining industry. The International Journal of Life Cycle Assessment, 16, 82-89. https: //doi.org/10.1007/s11367-010-0246-6

Ayres, R. U. (1995): Life cycle analysis: A critique. Resources, Conservation, Recycling, 14, 199-223. https://doi.org/ 10.1016/0921-3449(95)00017-D

Azapagic, A. (2004): Developing a framework for sustainable development indicators for the mining and minerals industry. Journal of Cleaner Production, 12, 6, 639-662. https:// doi.org/10.1016/S0959-6526(03)00075-1

Bartzas G. and Komnitsas K. (2015) Life cycle assessment of ferronickel production in Greece. Resources, Conservation, Recycling, 105, A, 113-122. https://doi.org/10.1016/j. resconrec.2015.10.016

Basu, A. J. and van Zyl, D. J. A. (2006): Industrial ecology framework for achieving cleaner production in the mining and minerals industry. Journal of Cleaner Production, 14, 3-4,299-304.https://doi.org/10.1016/j.jclepro.2004.10.008

Bongono, J., Elevli, B. and Laratte, B. (2020): Functional Unit for Impact Assessment in the Mining Sector-Part 1. Sustainability 12, no. 22: 9313. https://doi.org/10.3390/ su12229313

Budeš, I., Galić, I., and Dragičević, I. (2018). Research of bauxite deposits from underground mining works. Rudarsko-geološko-Naftni Zbornik (The Mining-GeologicalPetroleum Bulletin), 33(3), 95-110. Retrieved from https://hrcak.srce.hr/ojs/index.php/rgn/article/view/6263

Ciacci L., Eckelman, M. J., Passarini, F., Chen, W.-Q., Vassura, I. and Morselli, L. (2014): Historical evolution of greenhouse gas emissions from aluminum production at a country level. Journal of Cleaner Production, 84, 540-549. https://doi.org/10.1016/j.jclepro.2014.03.062

Eckelman, M. J. (2010) Facility-level energy and greenhouse gas life-cycle assessment of the global nickel industry. Resources, Conservation, Recycling, 54, 4, 256-266. https:// doi.org/10.1016/j.resconrec.2009.08.008

Ereiz, M. (2019): Studija utjecaja životnog ciklusa boksita eksploatiranog u Rudnicima boksita Jajce o. d. d. u razdoblju od 2010. do 2012. godine (Life cycle impact assessment study of bauxite extracted in Bauxite mines Jajce o.d.d. in period 2010 - 2012 : master's thesis). Sveučilište u Zagrebu, Rudarsko-geološko-naftni fakultet. (University of Zagreb, Faculty of Mining, Geology and Petroleum En- gineering), 48 p. (in Croatian, abstract in English). Accessed https://urn.nsk.hr/urn:nbn:hr:169:435570

Eržen, V,, Sabioncello, P. (1969): Eksplozivi (Explosives). Tehnička enciklopedija - Svezak 3. (Technical Enciclopedia. - Vol. 3) 528-537 p. (in Croatian, no English abstract)

European Commission -Joint Research Centre -Institute for Environment and Sustainability (2010): International Reference Life Cycle Data System (ILCD) Handbook - General guide for Life Cycle Assessment -Detailed guidance. First edition March 2010. EUR 24708 EN. Luxembourg. Publications Office of the European Union, 394 p. Retrieved from: https://eplca.jrc.ec.europa.eu/uploads/ILCDHandbook-General-guide-for-LCA-DETAILED-GUIDANCE-12March2010-ISBN-fin-v1.0-EN.pdf

European Commission (2019). Communication from the Commission to the European Parliament, The European Council, The Council, The European Economic and Social Committee and The Committee of the Regions. The European Green Deal. COM/2019/640 final. EUR-Lex -520 19DC0640-EN.

Retrieved from: https://eur-lex.europa.eu/legal-content/EN/ TXT/HTML/?uri=CELEX:52019DC0640\&from=EN (Accessed 18th October, 2020)

European Commission (2020). Communication from the Commission to the European Parliament, The European Council, The Council, The European Economic and Social Committee and The Committee of the Regions. Critical Raw Materials Resilience: Charting a Path towards greater Security and Sustainability. COM(2020) 474 final. EURLex - 52020DC0474 - EN. Retrieved from: https://eur-lex. europa.eu/legal-content/EN/TXT/?uri=CELEX:52020DC 0474\#footnote36 (Accessed $12^{\text {th }}$ April, 2021)

Farjana, S. H., Huda, N. and Mahmud, M. A. P. (2019): Life cycle assessment of cobalt extraction process. Journal of Sustainable Minining, 18, 150-161. https://doi.org/10. 1016/j.jsm.2019.03.002

Galić, I., Dragičević, I. and Radovac, T. (2006): Primjena računalnih programa pri modeliranju površinskih i podzemnih kopova. (Application computer programs at modeling open pit and underground minings) In: Žunec, N., Horvat, J. and Bunić, S. (eds.) Međunarodni rudarski simpozij - Mining 2006. Istraživanje, eksploatacija i prerada čvrstih mineralnih sirovina. Zagreb: Grafika Hrašće (in Croatian only)

Grbeš, A. (2016) A life cycle assessment of silica sand: Comparing the beneficiation processes. Sustainability, 8, 1-11. https://doi.org/10.3390/su8010011

Grbeš, A. (2014): Analiza ciklusa eksploatacije kvarcnoga pijeska u Hrvatskoj (Life Cycle Assessment of Silica Sand Exploitation and Processing in Croatia). PhD Thesis. Rudarsko-geološko-naftni fakultet, Zagreb. 146 p. (University of Zagreb, Faculty of Mining, Geology and Petroleum Engineering). (in Croatian, abstract available in English). https://www.bib.irb.hr/703909

Grbeš, A., Budeš, I., Barudžija, U. (2018): Life cycle inventory of underground mining of bauxite: A case from Bespelj mine in Bosna and Herzegovina. In: 2018 International Conference on Resource Sustainability. Beijing, $48-49$ 
ISO 14040:2006 (E): Environmental management — Life cycle assessment - Principles and framework. Second edition 2006-07-01

Kampmann, T. C., Alvarenga, R. A. F., Sanjuan-Delmás, D. and Lindblom, M. (2019): Life cycle assessment of European copper mining: A case study from Sweden. In Proceedings of the 15th SGA Biennial Meeting, Glasgow, UK, 27-30 August 2019; Society for Geology Applied to Mineral Deposits: Glasgow, Scotland, 2019; Volume 4, pp. 1577-1580. Retrieved from https://ltu.diva-portal.org/ smash/get/diva2:1347729/FULLTEXT03.pdf

Kvapil, R. (1992): Chapter 20.2. Sublevel Caving. In Hartman, H. L. et al. (eds.), Karmis, M. and Mealy G. A. (section eds.): SME Mining Engineering Handbook, 17891814

Norgate, T. and Haque, N. (2010): Energy and greenhouse gas impacts of mining and mineral processing operations. Journal of Cleaner Production, 18, 3, 266-274. https://doi. org/10.1016/j.jclepro.2009.09.020

Norgate, T. and Haque, N. (2012): Using life cycle assessment to evaluate some environmental impacts of gold production. Journal of Cleaner Production, 29-30, 53-63. https:// doi.org/10.1016/j.jclepro.2012.01.042

Northey, S., Mohr, S., Mudd, G. M., Weng, Z. and Giurco, D. (2014): Modelling future copper ore grade decline based on a detailed assessment of copper resources and mining. Resources, Conservation, Recycling, 83, 190-201 https:// doi.org/10.1016/j.resconrec.2013.10.005

Tomašić, N. (Ed) (2021): EIT Raw materials project REEBAUX. Final Report. Version No. 2. University of Zagreb -Faculty of Science. Project reference: 17089 REEBAUX Prospect of REE recovery from bauxite and bauxite residue in the ESEE region. Retrieved from http://reebaux.gfz. hr/wp-content/uploads/2021/02/REEBAUX_Final-report_2020_v2.pdf

Stewart, M. and Petrie, J. (2006): A process systems approach to life cycle inventories for minerals: South African and Australian case studies. Journal of Cleaner Production, 14, 12-13, 1042-1056. https://doi.org/10.1016/j.jclepro.2004. 08.008

\section{Unpublished literature:}

Dragičević, I. (1987): Paleogeografska evolucija rubnog dijela mezozojske karbonatne platforme Dinarida između Vrbasa i Bosne (Paleogeographic evolution of the marginal part of the Mesozoic carbonate platform of the Dinarides between Vrbas and Bosnia). Sveučilište u Zagrebu, Rudarskogeološko-naftni fakultet. (University of Zagreb, Faculty of Mining, Geology and Petroleum Engineering)
Galić, I. (2006): Glavni rudarski projekt eksploatacije ležišta boksita u eksploatacijskom polju “ Bešpelj”. (Main design of Bešpelj-Mine), Rudarsko-geološko-naftni fakultet, Zagreb.

Galić, I., Dragičević, I., H.,D. and Janković, B. (2007): Dopunski rudarski projekt eksploatacije ležišta boksita u eksploatacijskom polju "Bešpelj" (Supplementary design of Bešpelj-Mine), Sveučilište u Zagrebu, Rudarsko-geološkonaftni fakultet. (University of Zagreb, Faculty of Mining, Geology and Petroleum Engineering)

Marinkovic, R. and Ahac, A. (1975): Osnovna geološka karta SFRJ 1:100000, list Jajce (Basic geological map of Yugoslawia. Leaf Jajce)

Orlović-Leko, P. (2013): Kemija za rudare: Nastavni tekst (Chemistry for miners: Lectures). Sveučilište u Zagrebu, Rudarsko-geološko-naftni fakultet. (University of Zagreb, Faculty of Mining, Geology and Petroleum Engineering)

Papeš, J., Marinčić, J. and Bliznac, P. (2001): Elaborat o geološkoj i rudarskoj dokumentaciji o rezervama boksita u rudnicima Bešpelju i Poljanama kod Jajca u Bosni. Rudnici boksita Jajce. [Study on geological and mining documentation on bauxite reserves in the mines Bešpelj and Poljane near Jajce in Bosnia)

Tomić, V. (1983): Stratigrafija i paleogeografija kredno-paleogenskog boksitonosnog područja Jajca (Stratigraphy and paleogeography of the Cretaceous-Paleogene bauxitebearing area of Jajce.) Sveučilište u Zagrebu, Rudarskogeološko-naftni fakultet. (University of Zagreb, Faculty of Mining, Geology and Petroleum Engineering)

\section{Internet sources:}

European Commission (2020) Research and innovation for the European Green Deal.

URL1: https:/ec.europa.eu/info/research-and-innovation/ strategy/european-green-deal_en (Accessed 18th October 2020)

EIT RawMaterials (2018): REEBAUX: Prospects of REE recovery from bauxite and bauxite residue in the ESEE region.

URL2: https://eitrawmaterials.eu/project/reebaux/ (Accessed 1st October, 2020)

Eksplo-promet (2020): Minerska oprema. katalog (Equipment for blasting. Catalogue).

URL3: https://www.eksplo-promet.hr/wp-content/uploads /2018/10/EKSPLO-PROMET-MINERSKA-OPREMAKATALOG.pdf (Non-English site; Accessed 1st October, 2020)

Interpromet (2019) Vitezit V20.

URL4: http://interpromet.com/vitezit-vitez/vitezit-v20/ (Non-English site; Accessed 15th November 2019) 


\section{SAŽETAK}

\section{Modeliranju pogodna inventarizacija životnoga ciklusa podzemne eksploatacije malih, grupiranih ležišta boksita: studija slučaja iz Rudnika boksita Jajce u Bosni i Hercegovini}

Cilj je ovoga rada inventarizacija životnoga ciklusa podzemne eksploatacije boksita iz malih grupiranih ležišta koja su karakteristična za boksite dinaridskoga tipa, u planinama oko Jajca, grada u Bosni i Hercegovini, u razdoblju od 2o1o. do 2020. godine. Model životnoga ciklusa izveden je za metodu eksploatacije podetažnim zarušavanjem i dobivanja rude bušenjem i miniranjem. Temelji se na podatcima internih poslovnih izvješća tvrtke te projektne dokumentacije. Istraživanje je obuhvatilo četiri rudnika smještena na tri eksploatacijska polja zatečena u različitim fazama života rudnika, različitim razinama tektonskih poremećaja i različitim vrstama energije za mehanizaciju: dizel, električna energija, komprimirani zrak. Glavni su rezultati ovoga istraživanja inventar podzemne eksploatacije boksita izrađen na temelju dugoročnih podataka, životni ciklus jednoga ležišta boksita te faktori emisija od miniranja. Podzemna eksploatacija u ovome slučaju pokazala se energetski intenzivna: potrebno je u prosjeku od 52 do $92 \mathrm{MJ} / \mathrm{t}$ (nasuprot $37 \mathrm{MJ} / \mathrm{t}$ kod površinske eksploatacije boksita u Italiji). Istodobno, podzemna eksploatacija boksita uzrokuje samo 5,6 - 6,4 \% transformacije prirodnoga zemljišta koje je iznad rudnika i ležišta. Izbor mehanizacije i energije može izravno utjecati na energetski intenzitet. To može utjecati na kvalitetu radne atmosfere, kao i na potencijalne utjecaje u podzemlju. Trenutačni se rad oslanja na električnu energiju kao glavni izvor energije za strojeve, što je povoljno za radnu atmosferu na lokalnoj razini iako se energetska učinkovitost smanjuje upotrebom komprimiranoga zraka kao mehaničke energije. Na državnoj razini utjecaji ovise o mješavini energije koja je još uvijek prilično ovisna o fosilnim gorivima. Inženjerska procjena emisija od miniranja upućuje na to da detonatori i amonij-nitratni eksploziv mogu postati važan izvor utjecaja na okoliš.

Rudarska industrija imala bi znatne koristi od čišće energije u proizvodnji električne energije. Treba dalje istražiti put zračne emisije kroz podzemni sustav, posebno olova i dušikovih spojeva.

\section{Ključne riječi:}

inventar životnoga ciklusa, podzemna eksploatacija, boksit, rudarstvo, LCA

\section{Author's contribution}

Anamarija Grbeš (1) (assistant professor, $\mathrm{PhD}$ ) performed the data analysis, presentation of the results and interpretation. Ivo Galić (2) (associate professor, $\mathrm{PhD}$ ) provided the description of the mining project with geology and tectonics. Branimir Farkaš (3) (postdoctoral researcher, $\mathrm{PhD}$ ) provided the graphical design and the description of the mining method, contributing to the system description. Ivan Budeš (4) (mag.ing.min) performed the field work, contributing to data collection and completion. 